\title{
The annexins: spatial and temporal coordination of signaling events during cellular stress
}

\author{
Katia Monastyrskaya · Eduard B. Babiychuk • \\ Annette Draeger
}

Received: 5 January 2009/Revised: 9 February 2009/Accepted: 27 March 2009/Published online: 21 April 2009

(c) Birkhäuser Verlag, Basel/Switzerland 2009

\begin{abstract}
Annexins are a family of structurally related, $\mathrm{Ca}^{2+}$-sensitive proteins that bind to negatively charged phospholipids and establish specific interactions with other lipids and lipid microdomains. They are present in all eukaryotic cells and share a common folding motif, the "annexin core", which incorporates $\mathrm{Ca}^{2+}$ - and membranebinding sites. Annexins participate in a variety of intracellular processes, ranging from the regulation of membrane dynamics to cell migration, proliferation, and apoptosis. Here we focus on the role of annexins in cellular signaling during stress. A chronic stress response triggers the activation of different intracellular pathways, resulting in profound changes in $\mathrm{Ca}^{2+}$ and $\mathrm{pH}$ homeostasis and the production of lipid second messengers. We review the latest data on how these changes are sensed by the annexins, which have the ability to simultaneously interact with specific lipid and protein moieties at the plasma membrane, contributing to stress adaptation via regulation of various signaling pathways.
\end{abstract}

Keywords Annexin - Membrane binding - Calcium . $\mathrm{pH} \cdot$ Signal transduction $\cdot$ Stress

\section{Introduction}

The plasma membrane is not just a barrier separating the cell from its environment, its proteins and lipids also coordinate and route the incoming and outgoing signals. The amplification and redistribution of signals are in many

K. Monastyrskaya $(\bowtie) \cdot$ E. B. Babiychuk · A. Draeger Department of Cell Biology, Institute of Anatomy, University of Bern, 3000 Bern 9, Switzerland e-mail: monastyk@ana.unibe.ch cases accomplished by a highly regulated intracellular release of $\mathrm{Ca}^{2+}$ or a controlled entry of $\mathrm{Ca}^{2+}$ through the plasma membrane. Chronic stress conditions are often accompanied by extracellular acidification, oxidative stress, cytokine-induced cell proliferation, and gene mutations [1]. There is a significant interplay between intracellular $\mathrm{Ca}^{2+}$ and $\mathrm{pH}$ homeostasis: changes in $\mathrm{pH}_{\mathrm{i}}$ are often accompanied by an alteration of $\left[\mathrm{Ca}^{2+}\right]_{\mathrm{i}}$, intracellular acidification correlates with a marked increase in $\left[\mathrm{Ca}^{2+}\right]_{\mathrm{i}}$ due to the altered activity of calcium-entry channels, release from intracellular stores and its decreased affinity for $\mathrm{Ca}^{2+}$-binding proteins [2, 3]. On the other hand, $\mathrm{Ca}^{2+}$ influx through store-operated channels mediates intracellular alkalinization [4], and the proteins involved in maintaining the $\mathrm{pH}$ homeostasis are regulated by $\mathrm{Ca}^{2+}$-binding proteins, which are activated by many stimuli (Ras, PKC) sensitive to $\left[\mathrm{Ca}^{2+}\right]_{\mathrm{i}}$ [5]. Extracellular stress factors can incite contraction, division, secretion, cytokine-induced cell proliferation, gene mutations, or apoptosis. The basic stress signal can be as variable as the cellular response and is dependent on the cell type and the extent of the stimulus. Members of the annexin protein family are characterized by their distinct $\mathrm{Ca}^{2+}-$ and phospholipid-binding properties and have the ability to converge at the plasma membrane during stress. They act as intracellular sensors discriminating the incoming signals and thus may provide each cell type with individuality in its reaction to the changing environment.

\section{$\mathrm{Ca}^{2+}$-binding proteins: the annexin family}

There are several classes of $\mathrm{Ca}^{2+}$-binding proteins ranging from $\mathrm{Ca}^{2+}$-gated channels within the membranes, proteins serving as $\mathrm{Ca}^{2+}$ buffers, and proteins that change their 
functions in response to $\mathrm{Ca}^{2+}$-binding, thus directly participating in the signaling [6]. Based on the structure of their $\mathrm{Ca}^{2+}$-binding sites, the $\mathrm{Ca}^{2+}$-binding proteins can be classified as EF-hand proteins, C2-domain proteins and annexin, or type-II, $\mathrm{Ca}^{2+}$-binding-site proteins. Annexins are a family of structurally related, $\mathrm{Ca}^{2+}$-sensitive proteins that bind to negatively charged phospholipids [7] and establish specific interactions with other lipids and lipid microdomains [8,9]. Annexins were initially discovered as proteins, mediating the $\mathrm{Ca}^{2+}$-dependent aggregation of chromaffin granules [10]. Synexin, now known as human annexin A7, was the first member of the family whose $\mathrm{Ca}^{2+}$ - and membrane-binding properties were extensively studied [11]. Its discovery was followed by annexins A1 and A2 (then called lipocortin and calpactin), identified as substrates of $\mathrm{Src}$ and EGF protein kinases $[12,13]$. Already the early studies identified a complex between annexin A2 and a member of EF-hand $\mathrm{Ca}^{2+}$-binding S100 protein p11 (S100A10) [14]. The interaction of annexins with $\mathrm{S} 100$ proteins is a feature shared by most members of the family [15]. The 12 vertebrate annexins form the A family (annexins A1-A13, A12 left unassigned). The other annexins are currently classified into families B (invertebrates), C (fungi and unicellular eukaryotes), D (plants), and E (protists) [16]. The structure and diverse functions of annexins have been extensively reviewed [7, 17-19], so here we will only give a brief overview of the important features of these molecules, before concentrating specifically on their role in cell signaling events occurring at the plasma membrane during intracellular stress.

\section{Molecular structure of annexins}

All annexins possess a common folding motif, the C-terminal "core domain" [16]. The core domain incorporates functional sequences that are common for all members of the annexin protein family including $\mathrm{Ca}^{2+}$ binding sites and sites responsible for the interactions with negatively charged phospholipids. In contrast, the $\mathrm{NH}_{2}-$ terminal domains are variable and are thought to confer specific properties of each individual annexin.

Crystal structures of annexins have been determined for the core domains and proteins with short $\mathrm{NH}_{2}$-termini [20-22]. The $\mathrm{Ca}^{2+}$-binding sites of all annexins are located within the conserved core domain, comprising four (eight in the case of annexin A6) annexin repeats, each 70 amino acids long, forming five $\alpha$-helices connected by short loops. The annexin core has the shape of a slightly curved disc, with $\mathrm{Ca}^{2+}$ - and lipid-binding sites located at the convex face of the molecule. $\mathrm{Ca}^{2+}$, which is essential for the membrane interaction of most annexins, simultaneously coordinates carbonyl and carboxyl groups of the protein and phosphoryl groups at the glycerol backbone of membrane phospholipids [23]. $\mathrm{Ca}^{2+}$ binding leads to the conformational changes in the core domain, particularly in repeat III $[8,20,24]$.

The variability of the $\mathrm{NH}_{2}$-termini is thought to influence the specificity of the $\mathrm{Ca}^{2+}$ - and phospholipid-binding ability of the annexins. The $\mathrm{NH}_{2}$-terminal domains of annexins harbor sites for post-translational modification as well as for the interaction with other proteins [17]. The EF-hand proteins of the S100 family form the largest group of annexin-associated proteins, which are bound to the $\mathrm{NH}_{2}$-termini of annexins. The interaction of different annexins with $\mathrm{S} 100$ proteins has been the subject of two recent reviews [15, 25]. Here we discuss the annexin A2-S100A10 complex because its formation significantly alters the properties of annexin A2 and is implicated in many regulatory functions. Annexin A2 exists as a monomer (p36) or a heterotetramer (p90), in which two annexin molecules are associated with a dimer of S100A10 (p11). Annexin A2 forms a $\mathrm{Ca}^{2+}$-independent complex with S100A10, whereas the interaction of other annexins with S100 proteins, e.g. the association of annexin A1 with S100A11, requires $\mathrm{Ca}^{2+}$. Mutagenesis analysis showed that the $\mathrm{NH}_{2}$-terminal domain of annexin A2 regulates $\mathrm{Ca}^{2+}$-dependent membrane aggregation [26]. Due to the formation of a heterotetrameric complex with S100A10, annexin A2 gains the ability to aggregate membranes at micromolar $\mathrm{Ca}^{2+}$ concentrations [7].

The effects of the $\mathrm{NH}_{2}$-termini on $\mathrm{Ca}^{2+}$ binding are modulated not only via their modifications such as phosphorylation or binding to other proteins, but also directly following the conformational changes in this region of the molecule [27]. The role of the $\mathrm{NH}_{2}$-terminus in the modulation of $\mathrm{Ca}^{2+}$ sensitivity of lipid binding is apparent in the case of annexin A1. Truncated annexin A1 has a typical core structure [28], resembling annexin A5 and the core domain of annexin A2. The $\mathrm{NH}_{2}$-terminus of the fulllength protein inserts into the core, replacing and unwinding one of the helices. Upon $\mathrm{Ca}^{2+}$ and membrane binding, the $\mathrm{NH}_{2}$-terminus is expelled from the molecule and becomes available for other interactions, and the core $\mathrm{Ca}^{2+}$ binding site is restored [29]. It is possible that in the absence of $\mathrm{Ca}^{2+}$ ions, annexin $\mathrm{A} 1$ might be in its inactive form, and only after $\mathrm{Ca}^{2+}$ and/or phospholipid-binding, which promote an overall conformational change, annexin A1 assumes a structure allowing it to aggregate membranes.

Some annexins, including annexin A1, A2, A4, and A7 can promote membrane interaction in vitro, which has led to the hypothesis of their involvement in endocytosis and exocytosis. The mechanism of simultaneous interactions with two membranes could be either via protein-protein interactions, such as the one described for the A2-S100A10 
heterotetramer [30], or directly via two independent membrane-binding sites within one annexin molecule [31, 32]. Alternatively, since annexin A1 binds S100A11 protein in a $\mathrm{Ca}^{2+}$-dependent manner, the complex might form a symmetrical membrane-binding unit, linking two membranes [33]. Annexin A6 contains two cores, which are flexible and can orient themselves, allowing the molecule to interact with one or two membranes [34].

\section{Expression and distribution of annexins}

The expression of multiple annexins within each cell and the high similarity of the annexin molecular structure indicate the importance of these proteins. Indeed, although the distribution of annexins varies in human tissues and organs, these proteins are highly abundant in smooth muscle (annexins A1, A2, A4, A6) [8, 35], cardiomyocytes (annexins A4, A5, A6, and A7) [36], and endothelial cells (annexins A1, A2, A5, and A6) [37]. On the other hand, expression of some annexins is restricted to specific tissue types: annexin A3 to neutrophils and placenta, annexin A8 to skin, annexin A9 to tongue, and annexin A13 to small intestine [38-40].

When cellular functions deteriorate, frequent changes in the expression levels of annexins are observed [41]. Notably, most forms of human cancer are associated with significant alterations in the expression pattern of annexins, consistent with the role of these proteins in linking plasma membrane to cytoskeleton, maintenance of intracellular contacts, and endocytosis [42]. Annexins A1, A2, A4, and A6 are down-regulated in prostate cancer [43], and annexin A7 is a candidate tumor suppressor gene in prostate cancer, inhibiting prostate cell migration [44]. In acontractile bladders, concomitant with degenerative changes in smooth muscle cells, the expression of annexin A6 is reduced, which might have a bearing on the fine-tuning of the contractile apparatus [45].

At low $\left[\mathrm{Ca}^{2+}\right]_{i}$, annexins are diffusely distributed throughout the cytosol. After stimulation and $\left[\mathrm{Ca}^{2+}\right]_{i}$ elevation, they translocate to cellular membranes [35] (Fig. 1). Annexin A2 is involved in intracellular vesicle movement [46] and is associated with endosomal function. Endosomal localization has also been reported for annexins A1 and A6 [47, 48]. Annexin A5 has previously been associated with late endosomes [49, 50]. Annexins A5 and A6 have been associated with the Golgi apparatus, vacuolar membranes, and the endoplasmic reticulum [50, 51]. Several annexins (among them annexins A1 and A5) have been localized to the nucleus [52]. Hence, the intracellular translocation of annexins represents an important mechanism for targeting specific substrates and for the control of individual protein or lipid function.
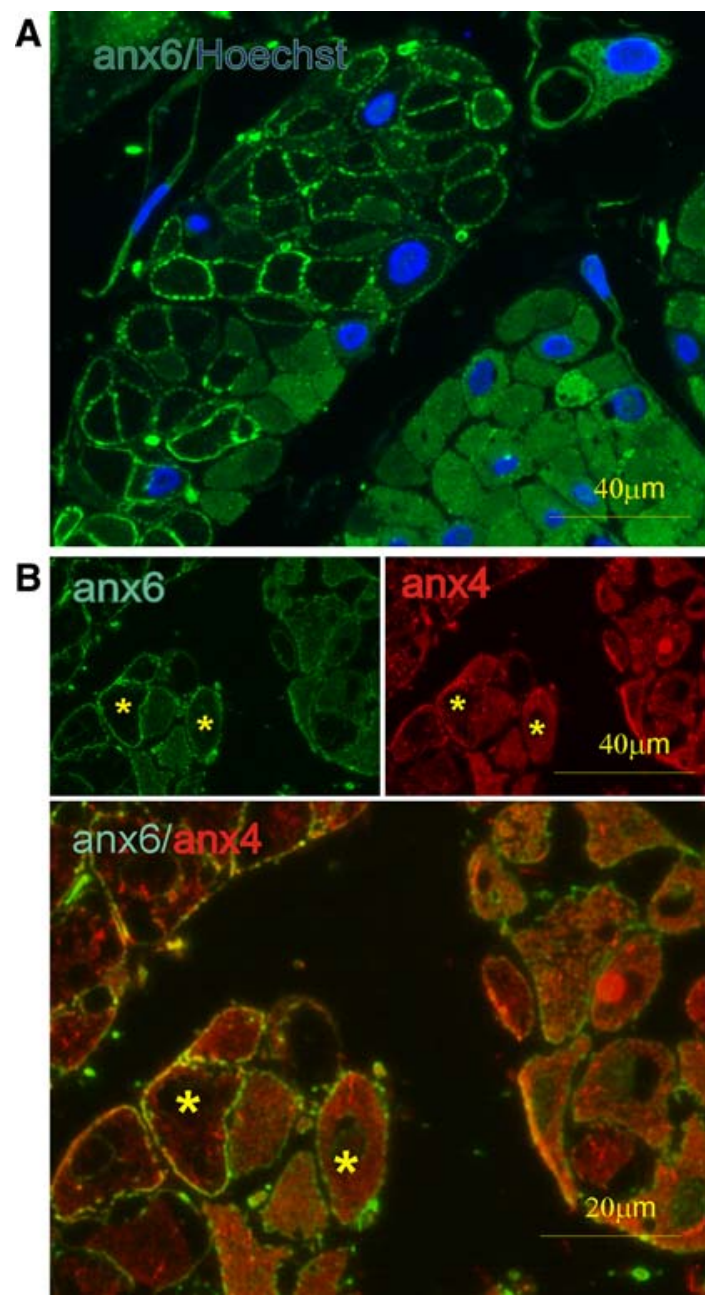

Fig. $1 \mathrm{Ca}^{2+}$-dependent localization of annexins $\mathrm{A} 4$ and $\mathrm{A} 6$ in smooth muscle cells. Fluorescent micrographs of transverse ultrathin cryosections through human myometrium. a Double labeling with a monoclonal antibody against annexin A6 (anx6: green) and nuclear dye Hoechst (Hoechst: blue). Contracted cells are outlined by annexin A6 translocation to the plasma membrane, whereas in relaxed cells, this protein shows a diffuse cytoplasmic distribution. b Double labeling with a polyclonal antibody against annexin A6 (anx6: green) and a monoclonal one against annexin A4 (anx4: red). Note the cytoplasmic localization of annexin A4 in contrast to plasma membrane-associated annexin A6 (asterisks), indicating that in some cells, $\left[\mathrm{Ca}^{2+}\right]_{i}$ is above annexin A6's, but below annexin A4's sensitivity for membrane translocation

\section{Annexins regulate plasma membrane architecture}

Annexins interact with specific lipids

Annexins are defined through their ability to bind negatively charged phospholipids, however, there are differences in binding to phospholipids with particular headgroups [phosphatidylserine (PS), phosphatidylinositol (PI), phosphatidic acid (PA)] [53]. Negatively charged phospholipids best promote binding of most annexins to 
phosphatidylcholine (PC)-containing membranes [54]. A comparison of 11 different types of lipids revealed that other factors such as the type of ion contributing the charge and head-group size were also important. Mixing phosphatidylserine and phosphatidylethanolamine or phosphatidylserine and phosphatidylinositol in the same PC vesicle synergistically enhanced annexin A4-membrane binding [54].

Lipid $\mathrm{A}$ is an active component of bacterial endotoxin in the bacterial envelope [55]. Annexins A1 and A2 were found to bind to this lipid, and the binding might have a role in suppressing the cellular and systemic responses to endotoxin by inhibiting its interactions with cellular receptors or accessory binding proteins [55].

Phosphatidylinositol 4,5-bisphosphate PtdIns $_{4,5} \mathrm{P}_{2}$ or $\mathrm{PIP}_{2}$ ) is a major phosphoinositide of the plasma membrane that comprises about $1 \%$ of the plasma membrane phospholipids [56]. PtdIns ${ }_{4,5} \mathrm{P}_{2}$ is the precursor of the second messengers inositol 1,4,5-triphosphate $\left(\mathrm{IP}_{3}\right)$ and diacylglycerol (DAG) [57] and plays a role in regulation of actin cytoskeleton [58]. PtdIns ${ }_{4,5} \mathrm{P}_{2}$ is a binding partner of annexin A2 at the sites of its membrane-dependent interaction with actin [59,60]. Direct binding of annexin A2 to PtdIns $_{4,5} \mathrm{P}_{2}$ in actin-rearrangement sites was demonstrated by Rescher et al. [60], who observed the accumulation of annexin A2 at the attachment sites of enteropathogenic E. coli, together with a concentration of cholesterol and an aggregation of GPI-anchored proteins [60, 61]. Simultaneously, in liposome sedimentation assays, Hayes et al. [59] demonstrated that recombinant annexin A2 bound to PtdIns $_{4,5} \mathrm{P}_{2}$ but not to other poly- and mono-phosphoinositides in the presence and absence of $\mathrm{Ca}^{2+}$. Since $\operatorname{PtdIns}_{4,5} \mathrm{P}_{2}$ is a precursor for many lipid second messengers $\left(\mathrm{IP}_{3}\right.$ and $\left.\mathrm{DAG}\right)$ and involved in vesicular trafficking and cell motility, these results support the role of annexin A2 in the regulation of membrane-cytoskeleton dynamics in vesicle trafficking and indicate a possibility of its involvement in other cell signaling events [59].

Cholesterol is an important membrane constituent, therefore the association of annexins with cholesterol and cholesterol-rich membranes was extensively investigated. Annexin A2 was shown to interact with cholesterol and its distribution was modulated by the subcellular distribution of cholesterol in cells from patients with the cholesterolstorage disorder Niemann-Pick C [47]. The authors conclude that annexin A2 forms cholesterol-containing platforms on early endosomal membranes and that these platforms regulate the onset of the degradation pathway in animal cells [47]. Annexin A2 was shown to interact with endosomal membranes independent of $\mathrm{Ca}^{2+}$ [62], and this binding was demonstrated to be mediated by cholesterol
[9, 63]. Annexin A2 is tightly membrane-associated in a cholesterol-dependent manner and interacts physically with elements of the cortical actin cytoskeleton. Taking into account these observations, the authors proposed that this protein serves as an interface between membranes containing high amounts of cholesterol and the actin cytoskeleton. In addition, annexin A2 is thought to play a role in cholesterol uptake: it associates with caveolin-1 in cultured cells during cholesterol uptake [64] and forms a tight complex with caveolin in zebrafish intestinal epithelium [65]. Annexin A2 plays an important role in exocytosis in chromaffin cells [66], where its function is mediated by cholesterol- and sphingomyelin-rich lipid microdomains (lipid rafts): annexin A2 influenced exocytosis via formation or stabilization of lipid rafts, and reduction of annexin $\mathrm{A} 2$ reduced exocytosis at the stage before membrane fusion [67]. The annexin A2-S100A10 complex is involved in the formation of E-cadherin-based adherens junctions, in a cholesterol-dependent manner [68]. However, biochemical data indicate that annexin A2 does not bind cholesterol directly, and these effects are strictly dependent on the presence of PS in liposomes [69]. Cholesterol in liposomes is able to increase $\mathrm{Ca}^{2+}$-dependent binding of $\mathrm{NH}_{2}$-terminally truncated annexins, showing that the $\mathrm{NH}_{2}$-terminus is not involved. Cholesterol increases the $\mathrm{Ca}^{2+}$ sensitivity of membrane binding of annexins A2 and A6, possibly by clustering/stabilizing PS-rich domains.

Similarly, annexins A5 and A6 show a cholesterol-mediated enhancement of their $\mathrm{Ca}^{2+}$-dependent binding to membranes, indicating that the annexin core domain is responsible for the cholesterol-mediated effects [70]. Annexin A6 is involved in the endocytosis of low-density lipoprotein (LDL) by regulating the entry of ligands into the pre-lysosomal compartment [71]. Cholesterol was shown to influence the membrane-binding affinity and intracellular distribution of annexin A6, and changes in its intracellular distribution and concentration in different subcellular compartments caused the reorganization of intracellular pools of annexin A6 [72]. Annexin A6 plays an important role in the transport of both cholesterol and caveolin. Cells expressing high levels of annexin A6 are characterized by an accumulation of caveolin-1 in the Golgi complex [73]. This was associated with a sequestration of cholesterol in the late endosomes and lower levels of cholesterol in the Golgi and the plasma membrane, both likely contributing to retention of caveolin in the Golgi apparatus and reduced number of caveolae at the cell surface. The elevated expression levels of annexin A6 perturb the intracellular distribution of cholesterol, indirectly inhibiting the exit of caveolin from the Golgi complex. 
Annexins and membrane rafts

Compartmentalization of the plasma membrane has been shown to be a prerequisite for the efficient and precise processing of signals across the plasma membrane. Lateral segregation of cholesterol- and sphingomyelin-rich lipid microdomains (rafts) and glycerophospholipid-containing non-raft regions has been proposed to play a role in a variety of biological processes [74-76]. The early studies indicated a $\mathrm{Ca}^{2+}$-dependent association of certain annexins with lipid rafts [77, 78]. In mammary epithelial cells, CD44, the major cell surface receptor for hyaluronic acid, was shown to localize to detergent-resistant cholesterolrich raft microdomains that contain annexin A2 at their cytoplasmic face. These CD44-containing lipid microdomains also interact with the underlying actin cytoskeleton [78]. When examining the structure of smooth-muscle plasmalemma, we showed that annexins A2 and A6 translocate to the detergent-resistant sites of the smoothmuscle cell in a $\mathrm{Ca}^{2+}$-dependent manner [8]. We further extended these observations by showing that the members of the annexin protein family each associate with different membrane compartments [79] (Fig. 2). Selective extraction of cholesterol prevents the relocation of annexin A6, but not of annexin A4 to the sarcolemma [35]. In contrast, the extraction of glycerophospholipids results in solubilization of annexins A1 and A4 whereas annexins A2 and A6 remain associated with the detergent-resistant membranes [35].

Upon binding, some members of the family have been shown to induce segregation of membrane lipids, with certain phospholipids accumulating underneath the sites of annexin attachment [80]. By means of scanning force and fluorescence microscopy of artificial membranes

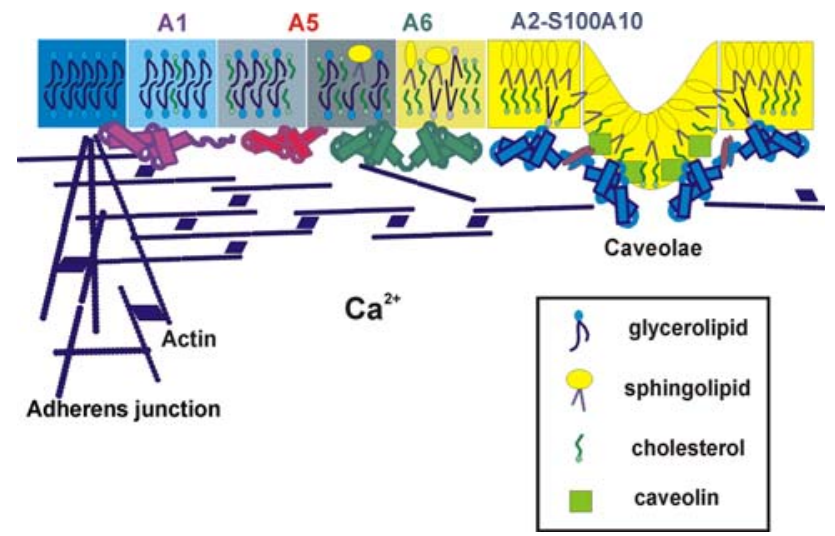

Fig. 2 Annexins interact with different lipid microdomains. Interdependent but not identical gradients of individual lipids exist within the membrane bilayer. The lipid moieties are responsible for targeting annexins to their respective places within the membrane. The segregation is further stabilized via an interaction of the membrane with the submembraneous cytoskeleton immobilized on mica surfaces, the lateral organization of the annexin A2-S100A10 heterotetramer and its influence on the lateral organization of the lipids within the membrane have been elucidated. A depletion of the 1-palmitoyl-2oleoyl-sn-glycero-3-phosphoserine domains was observed in the vicinity of annexin A2 tetramer protein domains, indicating that it was a peripheral membrane-binding complex capable of inducing lipid segregation [81]. Additionally, in the presence of $\mathrm{Ca}^{2+}$, annexin $\mathrm{A} 2$ caused the association of rafts [8]. It is therefore possible that the annexins might constitute a means of regulating $\mathrm{Ca}^{2+}$-dependent raft-assemblage [8]. In smooth-muscle cells, the raft binding of annexin A 2 could be interrupted following the proteolytic cleavage of the annexin [82]. This cleavage is initiated by calpain and is dependent on $\left[\mathrm{Ca}^{2+}\right]_{\mathrm{i}}$ and the presence of an intact contractile apparatus. Proteolysis abolishes annexin-binding to the plasma membrane and might result in the rearrangement of membrane constituents followed by the interruption of segregation-dependent signaling events [85].

The important function of annexins in raft organization was further strengthened by our experimental data showing that the structural changes in plasma membrane of contractile cells during development were accompanied by alterations of expression and localization of specific annexins [83]. The differences in skeletal and smoothmuscle sarcolemma can already be observed at the microdomain level and are characterized by a relative paucity of lipid rafts in differentiated skeletal muscle. However, the undifferentiated skeletal myoblasts and myotubes closely resemble smooth-muscle cells in their expression of raft-associated lipids and proteins. During differentiation in the early perinatal period, the plasma membrane of skeletal muscle undergoes a striking reorganization of its lipid and protein components; we showed that $5^{\prime}$-nucleotidase activity markedly decreased, concomitantly with transverse tubular invagination and terminal maturation of the skeletal-muscle sarcolemma. Simultaneously, membrane microdomain segregation became less apparent and raft-associated annexins A2 and A6 were downregulated. Annexin intracellular localization was also changing; the annexins were diffusely distributed within myotubes, transiently co-localized with caveolin-3 during embryogenesis, and expressed in the T-tubules within mature myocytes.

During monolayer culturing, smooth-muscle and endothelial cells are known to undergo dramatic cytoskeletal and plasma-membrane rearrangements. This extensive reorganization of the plasma membrane coincides with changes in the expression levels of the lipid raft marker proteins annexins A2, A6, and 5'-nucleotidase [84]. These three raft markers were massively upregulated in monolayer cultures of endothelial or smooth-muscle cells 
(single or co-cultures) compared with the levels in native smooth-muscle tissue or three-dimensional spheroids. Similarly, in the smooth-muscle cultures, the transition from normal spindle-shaped to epithelioid morphology is accompanied by structural changes in sarcolemma: the epithelioid cells had $30 \%$ higher levels of cholesterol and correspondingly lower levels of glycerophospholipids [85]. These changes in sarcolemmal lipid composition were associated with a reduced diversity in the range of membrane-binding annexins: expression of annexins A1, A4, A6, and A7 was lost, whereas the levels of annexins A2 and A5 were increased. Interestingly, in epithelioid cells, cholesterol was more susceptible to extraction, implicating loss of annexins and altered intracellular distribution of caveolin in membrane stabilization.

\section{Annexin A1 interacts with ceramide platforms}

The ability of annexins to sense $\mathrm{Ca}^{2+}$ signals and specific lipid second messengers is further elucidated in our recent study, which demonstrates the involvement of annexin A1 in the $\mathrm{Ca}^{2+}$-dependent production of ceramide and its clustering into platforms at the plasma membrane of living cells [86]. Ceramide is a key lipid mediator in cellular processes such as differentiation, proliferation, growth arrest, and apoptosis [87, 88]. Ceramide is synthesized de novo in the ER and transported to the Golgi apparatus where it is converted into complex sphingolipids. Alternatively, intracellular sphingomyelinases, triggered by a variety of pro-apoptotic signals, can convert sphingomyelin to ceramide at the plasma membrane [89]. Upon its genesis during apoptosis, ceramide self-associates into platforms, thereby promoting extensive structural changes within the plasma membrane [90, 91]. Hence, its classical role as a second messenger is being challenged in favor of a more general one, involving gross reorganization of membrane structure, clustering of signaling molecules, and an amplification of vesicle formation, fusion, and trafficking.

We showed that ceramide increased the affinity of annexin A1-membrane interaction [86]. In the physiologically relevant range of $\mathrm{Ca}^{2+}$ concentrations, this leads to an increase in the $\mathrm{Ca}^{2+}$-sensitivity of annexin A1-membrane interaction. Among proteins of the annexin family, the interaction with ceramide platforms is restricted to annexin A1 and is conveyed by its unique $\mathrm{NH}_{2}$-terminal domain (Fig. 3). Using fluorescently tagged annexin A1 as a reporter for ceramide platforms and annexin A6 as a nonselective membrane marker, we visualized ceramide platforms and provided evidence for a ceramide-driven segregation and internalization of membrane-associated proteins (Fig. 4).

Among other functions, annexin A1 is believed to act as a mediator of anti-inflammatory glucocorticoids [92].

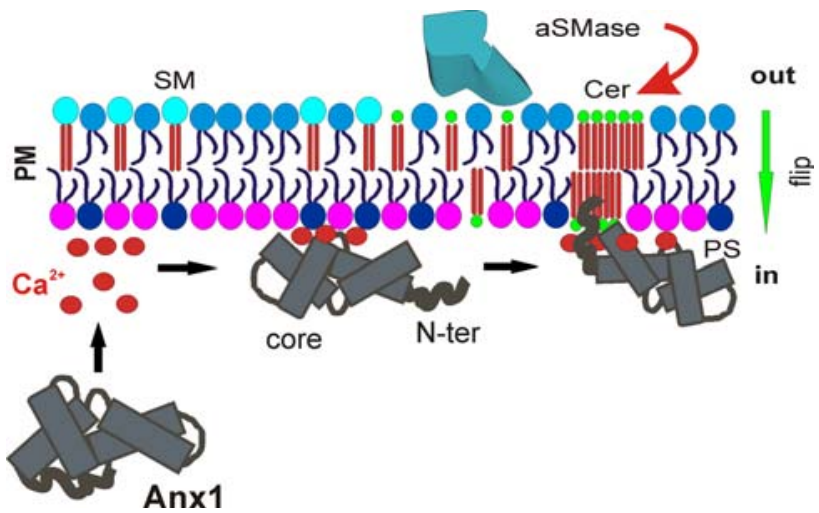

Fig. 3 The interaction between annexin A1 and ceramide platforms. Under conditions of stress, accompanied by sustained elevation of $\left[\mathrm{Ca}^{2+}\right]_{\mathrm{i}}$, acid sphingomyelinase (aSMase) converts sphingomyelin (SM) to ceramide (Cer) (red arrow). The green arrow indicates the spontaneous transbilayer equilibration of ceramide in the plasma membrane (PM) between the extra- and intracellular compartments (out, in). The $\mathrm{Ca}^{2+}$-mediated interaction between the annexin core and anionic phospholipids induces conformational changes in the annexin A1 molecule that result in the previously buried $\mathrm{NH}_{2}$-terminal domain becoming externally accessible. The unique $\mathrm{NH}_{2}$-terminus of annexin A1 conveys the selective interaction of the protein with the phase boundaries and its penetration into the highly ordered domains of tightly packed acyl chains formed in the membrane upon generation and self-association of ceramide. Anxl Annexin A1, core annexin A1 core domain, $N$-ter unique $\mathrm{NH}_{2}$-terminal domain of annexin $\mathrm{A} 1$

Annexin $\mathrm{A}^{-/-}$cell lines overexpress Cox-2 and cPLA2 and are insensitive to dexamethasone, implicating annexin A1 in the inhibition of inflammatory and proliferative signal transduction pathways [93]. Additionally, this protein plays a role in the execution of apoptosis [94] and the clearance of apoptotic cells by macrophages [95]. An interaction between annexin A1 and ceramide platforms occurs under conditions of cellular stress. Annexin A1 can influence the dynamic of lipid condensed domains in phospholipid monolayers [96]. This suggests that, in living cells, the formation of ceramide platforms might be promoted by annexin A1 binding. Annexin A1 has been shown to be released by apoptotic cells [95]. Our results indicate that the formation of ceramide platforms within the outer lipid bilayer together with the exposure of phosphatidylserine might serve as a stimulus for annexin A1 binding to apoptotic cells and mediate an annexin A1-dependent clearance of apoptotic cells by macrophages and annexin A1-induced apoptosis of surrounding cells [94].

Membrane curvature is sensed by annexin B12

Changes in membrane curvature take place during many cellular processes, including movement, division, and vesicular trafficking. Curvature can be dynamically modulated by changes in lipid composition, the oligomerization 
Fig. 4 Binding of annexin A1 to ceramide platforms under conditions of cellular stress. The formation of annexin A1-positive ceramide platforms was monitored in live Jurkat T-cells co-transfected with annexin A1-YFP (Anx1: yellow) and annexin A6-CFP (Anx6: blue). The cells were maintained in Tyrode's buffer containing $2 \mathrm{mM} \mathrm{CaCl}_{2}$ and challenged with $\mathrm{Ca}^{2+}$ / ionomycin at $30 \mathrm{~s}$. Data sets were obtained with a ZEISS LSM 510 Meta at the time points indicated. Sustained elevation of $\left[\mathrm{Ca}^{2+}\right]_{\mathrm{i}}$ results in the formation of ceramide, which accumulates within plasma membrane platforms (arrows). Annexin A1, but not annexin A6, associates with ceramide platforms
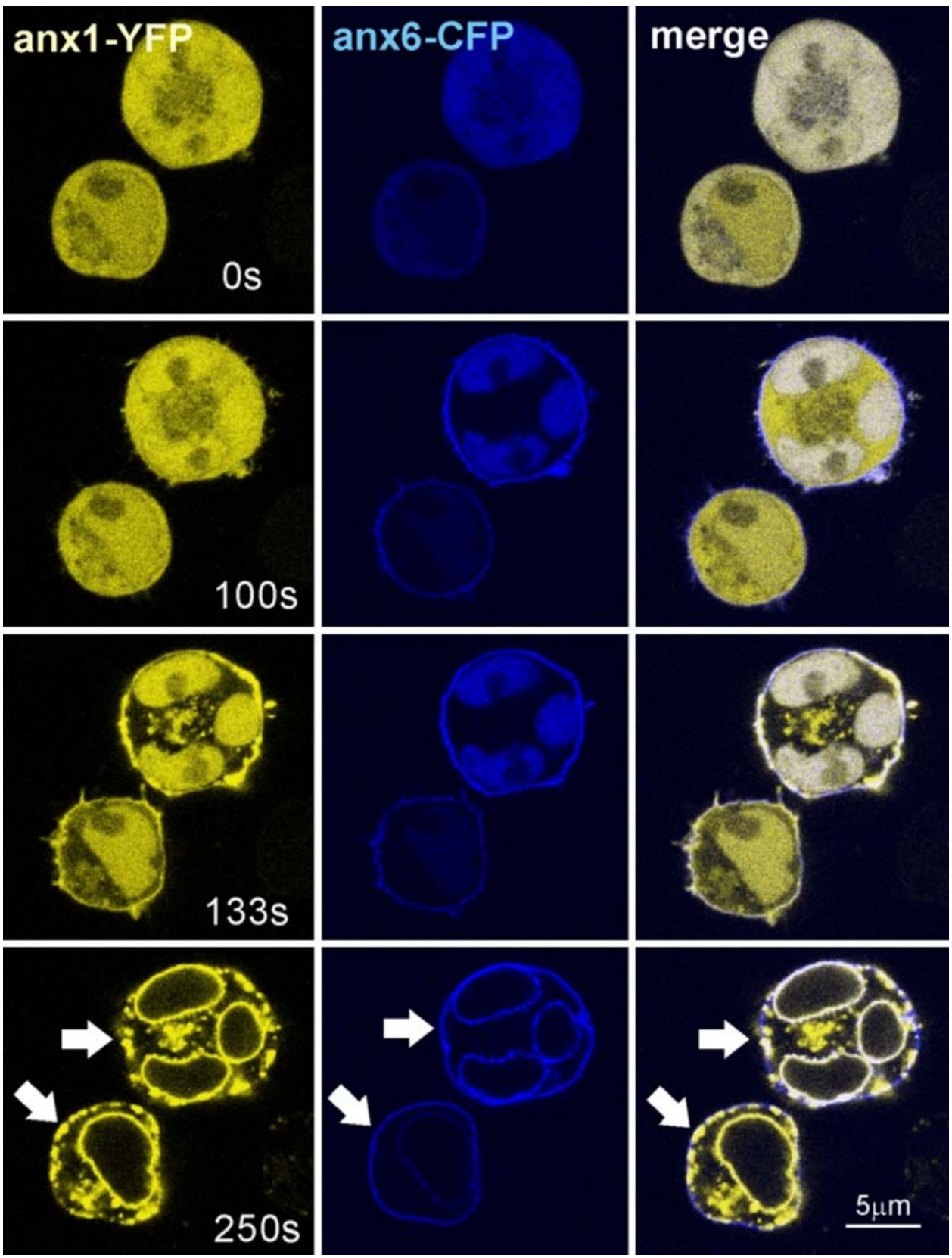

of curvature scaffolding proteins, and the reversible insertion of protein regions that act like wedges in membranes. There is an interplay between curvature-generating and curvature-sensing proteins during vesicle budding [97]. For example, the Golgi-associated protein ArfGAP1 has an unusual membrane-adsorbing amphipathic alpha-helix: its polar face is weakly charged, containing mainly serine and threonine residues, and it was shown that this feature explained the specificity of ArfGAP1 for curved versus flat lipid membranes [98].

In a recent study by Fischer et al. [99], a combination of biochemical and biophysical approaches was used to analyze the interaction of annexin B12 with membranes of different curvatures. The authors observed a selective and $\mathrm{Ca}^{2+}$-independent binding of annexin B12 to negatively charged vesicles that were either highly curved or contained lipids with a negative intrinsic curvature. This novel curvature-dependent membrane interaction induced major structural rearrangements in the annexin protein and resulted in a backbone fold that was different from that of the well characterized $\mathrm{Ca}^{2+}$-dependent membrane-bound form of annexin B12. Following curvature-dependent membrane interaction, the protein retained a predominantly alpha-helical structure but underwent inside-out refolding that brought previously buried hydrophobic residues into contact with the membrane. These structural changes were 
reminiscent of those previously observed following a $\mathrm{Ca}^{2+}$-independent interaction of annexins with membranes at mildly acidic $\mathrm{pH}$ (see below), yet they occurred at neutral $\mathrm{pH}$ in the presence of curved membranes. Therefore, annexin B12 could be a sensor of membrane curvature, thus explaining the previously reported $\mathrm{Ca}^{2+}$-independent membrane interaction of annexins in vivo occurring at neutral $\mathrm{pH}$.

Many signaling proteins are modulated by changes in lipid composition and concomitant alterations of the curvature. The activity of membrane-associated PKC was shown to be tightly controlled by the physical properties of the membrane lipid bilayer, in particular, curvature stress, which is induced by bilayer-destabilizing lipid components $[100,101]$. It is therefore possible that the ability of annexins to sense lipid-induced changes in membrane curvature could bring them into contact with other signaling molecules at the plasma membrane, i.e. PKC, and thus allow them to modulate different signaling pathways both $\mathrm{Ca}^{2+}$-dependently and $\mathrm{Ca}^{2+}$-independently.

\section{Annexins and the cytoskeleton}

The cortical cytoskeleton has an important function in stabilizing the plasma membrane and is involved in the regulation of multiple cellular processes under normal conditions and during stress. Several members of the annexin family are capable of binding to actin [102]. Annexin A2 binds F-actin [103], and its knock-down decreases the migration of human glioma cells [104]. Annexin A2 is essential for actin-dependent vesicle transport, as discussed above $[59,105]$. In spontaneously motile cells, Hayes et al. [106] demonstrated that annexin A2 was observed in dynamic actin-rich protrusions, and its depletion led to the accumulation of stress fibers and loss of protrusive and retractile activity. Annexin A2 reduced the polymerization rate of actin monomers in a dose-dependent manner by inhibiting the filament elongation at the barbed ends. These results point to the essential role of annexin $\mathrm{A} 2$ in the plasticity of a dynamic, membrane-associated actin cytoskeleton, achieved through direct interactions with polymerized and monomeric actin [106]. In polarized epithelial cells, annexin A2 in complex with S100A10 and AHNAK protein recruit the cortical actin cytoskeleton and have been implicated in the regulation of the actin cytoskeleton organization at the lateral plasma membrane [107].

Recently, it has been shown that leukemia-cell-associated annexin $\mathrm{A} 8$ binds $\mathrm{Ca}^{2+}$-dependently and with high specificity to PtdIns ${ }_{4,5} \mathrm{P}_{2}$, interacts with F-actin, and associates with late endosomes [108, 109]. Interestingly, these properties of annexin A8 closely resemble annexin A2, which could be an indication of the functional redundancy within the annexin protein family.
The role of annexin A6 in endocytosis has been linked to cytoskeletal modification [110]. It is required for the budding of clathrin-coated pits from human fibroblast plasma membranes: annexin A6 binds to $\beta$-spectrin at the cell surface, consequently recruiting and activating a calpainlike protease. This seems to open the actin cytoskeleton to facilitate the initial steps of endocytosis. In smooth-muscle cells, annexin A6 together with annexin A2 forms a $\mathrm{Ca}^{2+}$ dependent, plasmalemmal complex with actin filaments [111]. These annexins can also associate with F-actincontaining stress fibers in cultured smooth-muscle cells or fibroblasts in a $\mathrm{Ca}^{2+}$-independent manner [112]. A complex of annexin A6 with actin has been suggested to stabilize the cardiomyocyte sarcolemma during cell stimulation [113].

In activated platelets, in high $\left[\mathrm{Ca}^{2+}\right]$, annexin A5 was shown to associate with the cortical cytoskeleton by forming a specific bond to $\gamma$-actin [114]. Similarly, annexin A1 has been identified as a $\mathrm{Ca}^{2+}$ - and F-actin-binding protein in fractionated brain cortex [115]. In addition, annexin A1 interacts with profilin [116]. The interaction between annexin A1 and profilin was implicated in the regulation of the dynamic membrane-cytoskeleton organization, based on the submembrane localization of annexin A1 and the regulatory activity of profilin on the cytoskeleton [117]. During the onset of diabetes, the endothelial plasma membrane proteins actin, annexin A1, annexin A2, the p34 subunit of the Arp2/3 complex, and the Ras suppressor protein-1 become glycated [118]. The authors suggest that the nonenzymatic glycosylation of the cortical cytoskeleton-associated proteins has possible consequences for the fluidity of the endothelial plasma membrane and impairment of the endothelial mechanotransducing ability during hyperglycemia.

Annexins require different $\left[\mathrm{Ca}^{2+}\right]_{\mathrm{i}}$ for membrane interaction

Earlier studies using synthetic lipid vesicles [53, 54], chromaffin granules [26], and neutrophil secretory vesicles [119] demonstrated that annexins have diverse $\mathrm{Ca}^{2+}$ sensitivities of lipid binding. The individual $\left[\mathrm{Ca}^{2+}\right]$ required for this association differ greatly, depending on the experimental setup and the source of the protein, which complicates a comparison of the data. In addition, the lipid composition of the bilayer is known to influence the affinity of annexins to the synthetic membranes [120].

Smooth-muscle-cell contraction is regulated by changes in $\left[\mathrm{Ca}^{2+}\right]_{\mathrm{i}}$. The smooth muscle expresses a broad array of annexins [111]. Using biochemical methods, we showed that each annexin required a subtly different individual level of free calcium for its translocation to the plasma membrane [35]: around $300 \mathrm{nM}$ for annexin A2, $700 \mathrm{nM}$ 
for annexin $\mathrm{A} 6,1 \mu \mathrm{M}$ for annexin $\mathrm{A} 4$, and $1.5 \mu \mathrm{M}$ for annexin A1. Similarly, when examining the $\mathrm{Ca}^{2+}$-induced translocations of four members of the annexin family and of two truncated annexins in live cells, we demonstrated that these proteins interact with the plasma membrane as well as with internal membrane systems in a highly coordinated manner [121]. In cells stimulated with ATP or carbachol, annexin A2 briefly associates with the plasma membrane during the transient elevation in $\left[\mathrm{Ca}^{2+}\right]_{\mathrm{i}}$ corresponding to a $\mathrm{Ca}^{2+}$ release from intracellular stores (Fig. 5a). Simultaneous $\mathrm{Ca}^{2+}$ imaging in transfected cells showed that the timing and duration of this association exactly corresponds to the $\left[\mathrm{Ca}^{2+}\right]_{\mathrm{i}}$ elevation. Annexin A6 translocated to the plasma membrane only when a sustained $\mathrm{Ca}^{2+}$ influx was induced by activation of storeoperated channels with thapsigargin (Fig. 5b). A similar behavior has been observed for PKC $\alpha$ in differentiated PC12 cells following stimulation of ionotropic P2X receptors [122]. Hence, apart from the amplitude, the duration and/or the site of the influx (close to the plasma membrane) influenced the translocation of annexin A6. Annexin A2 is the most $\mathrm{Ca}^{2+}$-sensitive of the studied proteins, followed by annexin A6, annexin A4, and annexin A1 (Fig. 5c). The calcium sensitivity of annexin A2 increases further following association with S100A10 [121]. Upon elevation of $\left[\mathrm{Ca}^{2+}\right]_{i}$, annexins $\mathrm{A} 2$ and $\mathrm{A} 6$ translocate to the plasma membrane, whereas annexins A4 and A1 also become associated with intracellular membranes and the nuclear envelope. The $\mathrm{NH}_{2}$-terminus has a modulatory effect on plasma membrane binding: its truncation increases the $\mathrm{Ca}^{2+}$ sensitivity of annexin $\mathrm{A} 1$ and decreases that of annexin A2 [121].

A study carried out using fluorescent protein-tagged annexins in neuroblastoma cells resulted in essentially the same order of $\mathrm{Ca}^{2+}$ sensitivity [123]. The FRET experiments revealed that most annexins were likely to occupy particular membrane regions, with very little lateral mobility. Given the fact that several annexins are present within any one cell, it is likely that they form a sophisticated $\left[\mathrm{Ca}^{2+}\right]$ sensing system, with a regulatory influence on other signaling pathways.

pH-dependent membrane interaction and channel activity of annexins

Apart from the typical $\mathrm{Ca}^{2+}$-dependent membrane binding described above, annexins have the ability to associate with both synthetic and natural membranes in the absence of $\mathrm{Ca}^{2+}$ [124-126], which points to the existence of pH-dependent binding mechanisms, most likely mediated by hydrophobic interactions. Isas et al. [127] reported that
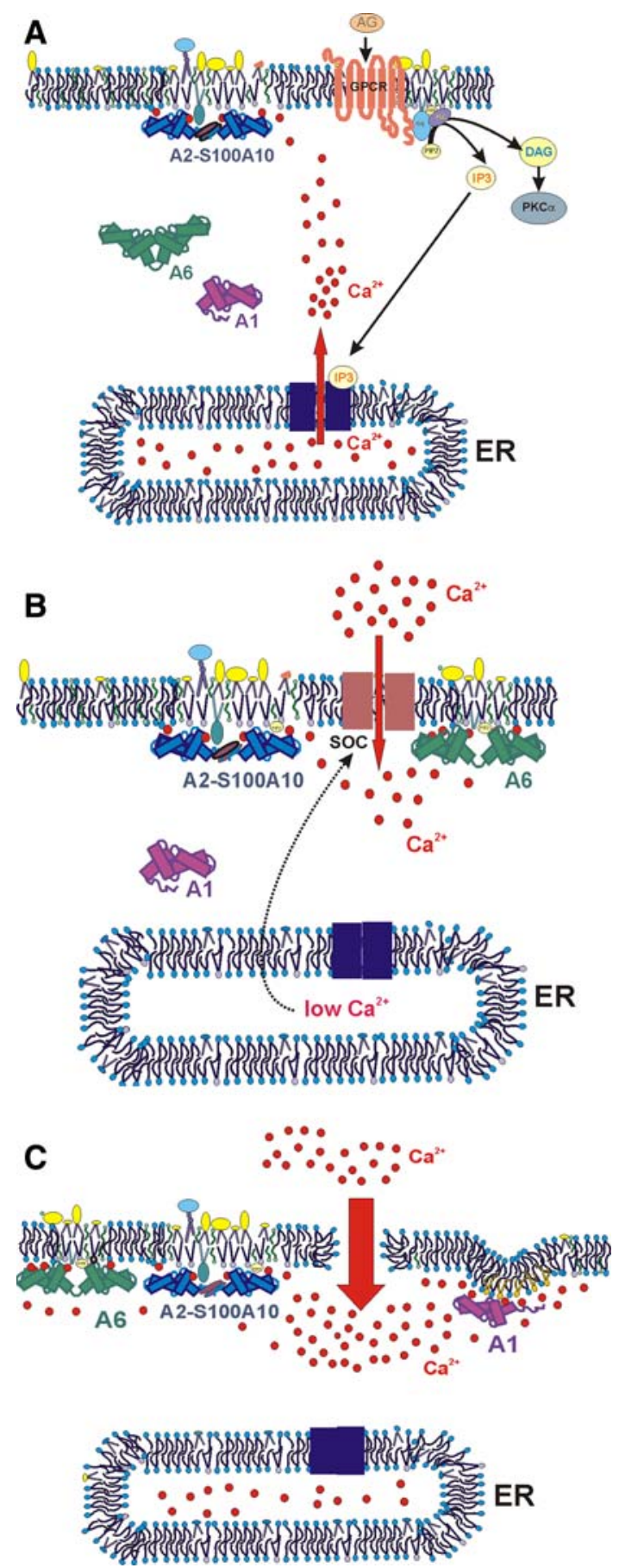

Fig. 5 Annexins discriminate between the magnitude and duration of $\mathrm{Ca}^{2+}$ signals. Different $\mathrm{Ca}^{2+}$ sensitivities of annexins allow them to interact with the plasma membrane under specific conditions. a $\mathrm{Ca}^{2+}$ transients caused by $\mathrm{IP}_{3}$-mediated release from intracellular stores (ER) are sensed by the annexin A2-S100A10 complex, which translocates to the plasma membrane. b Store-operated $\mathrm{Ca}^{2+}$ entry activated by an empty ER results in the plasma membrane translocation of annexin A6 and annexin A2. c Prolonged elevation of $\left[\mathrm{Ca}^{2+}\right]_{\mathrm{i}}$, occurring during stress and membrane damage, causes PM association of annexin A1, which preferentially binds to ceramiderich areas 
human annexin A5 and hydra annexin B12 were able to bind phospholipid vesicles in vitro at $\mathrm{pH} 5.3$ and 5.8, respectively. Similar interactions were described in further studies of annexins B12 [125, 128] and human annexin A6 [124, 129]. It should be noted that these studies were performed in vitro at $\mathrm{pH}$ between 4 and 6 , i.e., under conditions that rarely occur in living cells.

We characterized in vivo the influence of intracellular $\mathrm{pH}$ on $\left[\mathrm{Ca}^{2+}\right]_{\mathrm{i}}$ and membrane association of human annexins A1, A2, A4, A5, and A6 tagged with fluorescent proteins [130]. Annexin A6 and the heterotetramer A2S100A10 (p11) - but not annexins A1, A4, and A5- $\mathrm{Ca}^{2+}$ independently interact with the plasma membrane at $\mathrm{pH}$ 6.6 and 6.8. The dimerisation of annexin A2 within the annexin A2-S100A10 complex is essential for the $\mathrm{pH}$-dependent membrane interaction at this $\mathrm{pH}$ range. The observations that annexin A6 interacts with membranes of late endosomes [71] and annexin A5 induces $\mathrm{pH}$-dependent vesicle aggregation and fusion [131] point to the fact that the local acidic microenvironment of certain intracellular compartments allows such $\mathrm{Ca}^{2+}$-independent membrane interactions to occur in vivo.

Two types of $\mathrm{pH}$-induced membrane interactions have been proposed: protein insertion into the membrane bilayer, resulting in a transmembrane annexin, and the membrane binding associated with increased hydrophobicity of annexins at acidic $\mathrm{pH}$. Exposure to low $\mathrm{pH}$ may cause a significant conformational change in the core domain generating a transmembrane form of the protein as suggested for annexins B12 [125, 132], A5 [127], and A6 [124, 133]. In contrast, no such dramatic rearrangement takes place in the case of annexins A1 and A2 [134]. Under mildly acidic conditions, annexin A2 binds to and aggregates membranes containing anionic phospholipids. Using time-resolved fluorescence analysis and the measurement of Stokes radius, Lambert et al. [134] demonstrated that at mildly acidic $\mathrm{pH}$, the protein undergoes conformational changes similar to those induced by $\mathrm{Ca}^{2+}$. These changes allow access to the hydrophobic part of the membrane at both acidic $\mathrm{pH}$ in the absence of $\mathrm{Ca}^{2+}$ and at neutral $\mathrm{pH}$ in the presence of $\mathrm{Ca}^{2+}$. However, membrane bridging by the annexin A2-S100A10 heterotetramer did not involve further structural modification of the protein core. The $\mathrm{NH}_{2}$-terminal domain of annexin A2 was implicated in mediating $\mathrm{pH}-$ induced membrane aggregation in vitro [135].

The issue of annexins acting as ion channels in their own right is somewhat controversial as such activity was only observed in vitro and usually requires low (below 6.0) $\mathrm{pH}$, which induces extensive alterations of the protein structure. Most annexins might be capable of forming membrane channels in vitro; first described for annexin A7 [136], this feature was observed also for annexins A5 [136], A2 [137], and A1 [138]. The crystallographic studies show a hydrophilic pore at the centre of the annexin molecule, forming a prominent ion channel coated with charged and highly conserved residues [139]. The cation/anion permeability ratios of the ion channels formed by several annexins confirm the selectivity of the annexin channels for $\mathrm{Ca}^{2+}$ over other divalent cations and reveal the importance of amino acid positions 17, 78, 95, and 112 for the identification of the ion channel's position, function, and regulation. However, the annexin-mediated ion conductance is reversely proportional to the concentration of $\mathrm{Ca}^{2+}$, and most annexins require high $\mathrm{Ca}^{2+}$ for membrane interaction. On the other hand, low $\mathrm{pH}$ favors membrane insertion of annexins (see above) and might therefore promote channel activity. Indeed, the mechanism of pore formation at low $\mathrm{pH}$ was proposed by Langen et al. [140] based on the membrane-inserted form of annexin B12 at low $\mathrm{pH}$. Upon $\mathrm{pH}$-induced membrane insertion, a continuous transmembrane alpha-helix is reversibly formed from a helix-loop-helix motif seen in the solution structure. The authors identified other regions with similar membraneinsertion potential in the amino acid sequence and proposed that the corresponding helices come together to form an aqueous pore mediating the ion channel activity reported for several annexins [140].

\section{Cell signaling and annexins}

Role of annexins in the regulation of intracellular $\mathrm{Ca}^{2+}$ homeostasis and modulation of ion channels

Annexin A6 is the most extensively investigated member of the family in terms of its influence on intracellular $\mathrm{Ca}^{2+}$ homeostasis and has been implicated in the regulation of the sarcoplasmic reticulum ryanodine-sensitive $\mathrm{Ca}^{2+}$ channel [141], the neuronal $\mathrm{K}^{+}$and $\mathrm{Ca}^{2+}$ channels [142], and the cardiac $\mathrm{Na}^{+} / \mathrm{Ca}^{2+}$ exchanger [143]. Studies with transgenic animals delineated an important function of annexin A6 in maintaining intracellular $\mathrm{Ca}^{2+}$ homeostasis. Cardiac-specific over-expression of annexin $\mathrm{A} 6$ resulted in lower basal $\left[\mathrm{Ca}^{2+}\right]$, a depression of $\left[\mathrm{Ca}^{2+}\right]_{\mathrm{i}}$ transients, and impaired cardiomyocyte contractility [144]. In contrast, the cardiomyocytes from annexin A6 null-mutants showed increased contractility and accelerated $\mathrm{Ca}^{2+}$ clearance [145]. Consistent with its role in mediating intracellular $\mathrm{Ca}^{2+}$ signals, especially $\mathrm{Ca}^{2+}$ influx, ectopic overexpression of annexin A6 in A431 cells, which lack endogenous annexin, resulted in inhibition of EGF-dependent $\mathrm{Ca}^{2+}$ entry [146].

Store-operated $\mathrm{Ca}^{2+}$ entry (SOCE) has been proposed as a main process controlling $\mathrm{Ca}^{2+}$ entry in non-excitable cells [147], and the recent discovery of Orai1 and STIM provided a missing link between the $\mathrm{Ca}^{2+}$-release-activated current 
$\left(I_{\text {CRAC }}\right)$ and the ER $\mathrm{Ca}^{2+}$ sensor [148-150]. The actin cytoskeleton plays a major role in the regulation of SOCE, possibly by influencing the function of ion channels or by interfering with the interaction between STIM and Orai1 [151-153]. However, the proteins connecting the actin cytoskeleton and SOCE activity have yet to be identified. We targeted annexin A6 to the plasma membrane independent of $\mathrm{Ca}^{2+}$ and demonstrated that the constitutive PM localization of annexin A6 resulted in down-regulation of store-operated $\mathrm{Ca}^{2+}$ entry (Monastyrskaya et al., unpublished data). Expression of membrane-anchored annexin A6 caused an accumulation of cortical F-actin, and cytoskeletal destabilization with latrunculin A abolished the inhibitory effect of plasma membrane-anchored annexin A6 on SOCE. Our results implicate annexin A6 in the maintenance of intracellular $\mathrm{Ca}^{2+}$ homeostasis via actin-dependent regulation of $\mathrm{Ca}^{2+}$ entry.

The role of annexins as regulators of ion channel activity has been addressed in a number of studies (reviewed in [154]). In epithelial cells, annexin A4 had an inhibitory effect on $\mathrm{Ca}^{2+}$-dependent $\mathrm{Cl}^{-}$conductance [155]. Using a specific peptide, corresponding to the $\mathrm{NH}_{2}$-terminus of annexin $\mathrm{A} 2$ and interfering with annexin A2-S100A10 complex formation, it was demonstrated that this annexin heterotetramer could be involved in the function of a volume-activated chloride channel in endothelial cells [156].

Recently, several studies implicated annexins in complex with S100 proteins in the regulation of trafficking and function of several ion channels. Transient receptor potential channels TRPV5 and TRPV6 have an important function in $\mathrm{Ca}^{2+}$ uptake by kidney and intestine epithelia [157]. These channels are constitutively active at low intracellular $\mathrm{Ca}^{2+}$ and physiological membrane potential and have a high selectivity for $\mathrm{Ca}^{2+}$. They are regulated by associated proteins, including calmodulin, 80K-H, Rab11a, $\mathrm{Na}^{+} / \mathrm{H}^{+}$exchanger regulatory factor 2 , and the annexin A2-S100A10 complex [158]. S100A10 has been identified as an auxiliary protein for these $\mathrm{Ca}^{2+}$ channels using a yeast two-hybrid system [159]. It was shown that annexin A2 heterotetramer was co-expressed with TRPV5 and TRPV6 in $\mathrm{Ca}^{2+}$-transporting epithelia and was essential for their function. Mutation of a sequence mediating the interaction of TRPV5 and TRPV6 with S100A10 caused a major disturbance in the intracellular localization of these channels, indicating that their complex with A2-S100A10 was mediating their correct trafficking. A similar complex was detected in airway epithelia [160], and its formation is regulated by the cAMP/PKA/calcineurin A pathway, which determines the association between annexin A2 and S100A10. The same signaling pathway promotes the interaction of the annexin A2-S100A10 complex with the cystic fibrosis conductance regulator protein (CFTR) and regulates its channel function [161, 162]. An acetylated peptide, corresponding to the $\mathrm{NH}_{2}$-terminus of annexin $\mathrm{A} 2$, harboring the S100A10 interaction site, was shown to interfere with A2-S100A10/CFTR complex formation, inhibiting the CFTR current in epithelia.

Similarly, the TWIK-related acid-sensitive $\mathrm{K}^{+}$channel (TASK1) was shown to be associated with S100A10 via its C-terminal amino acids [163]. This sequence (SSV) resembles the binding motif of TRPV channels, suggesting that both proteins share the binding pocket on S100A10. This feature, however, is not essential for the interaction, as the voltage-gated $\mathrm{Na}^{+}$channel $\left(\mathrm{Na}_{\mathrm{v}} 1.8\right)$ binds $\mathrm{S} 100 \mathrm{~A} 10$ via an unrelated $\mathrm{NH}_{2}$-terminus [164]. A dorsal root ganglionspecific knock-out of S100A10 allowed examination of its role in nociception [165]. The expression levels of annexin A2 were not affected, however, the S100A10-null neurons showed deficits in the expression of $\mathrm{Na}_{\mathrm{v}} 1.8$ and attenuation of acute pain behavior. The annexin A2-S100A10 complex with the acid-sensing ASIC1 channel was detected by immunoprecipitation in dorsal root ganglion neurons [166]. Taken together, these findings indicate that the S100A10annexin A2 complex plays an important role in the trafficking of several ion channels to the plasma membrane. The regulation of this complex by cAMP/PKA/calcineurin adds another important level of control of channel activity and allows the convergence of different intracellular pathways on the plasma membrane to be influenced by annexins.

\section{Regulation of PKC}

Similar to the annexins, $\mathrm{PKC} \alpha$ is a phospholipid-binding protein that translocates from the cytoplasm to the plasma membrane upon elevation of $\left[\mathrm{Ca}^{2+}\right]_{i}[167,168]$. DAG is a major activator of PKC. Addition of DAG to lipid membranes has been shown to increase $\mathrm{Ca}^{2+}$-binding of several annexins, in particular annexin A6 (E. Babiychuk, unpublished data). It is therefore possible that both proteins associate with similar areas of the plasma membrane upon intracellular stimulation and elevation of $\left[\mathrm{Ca}^{2+}\right]_{\mathrm{i}}$. Indeed, activated $\mathrm{PKC} \alpha$ was shown to associate with annexin $\mathrm{A} 6$ in skeletal muscle [169]. Unlike annexins A1, A2, and A4, annexin $\mathrm{A} 6$ is not phosphorylated by $\mathrm{PKC} \alpha$ and might regulate $\mathrm{Ca}^{2+}$-dependent PKC activity, either by targeting the PKC to specific intracellular locations or by competitive inhibition thus enhancing signal termination [169]. Upon activation, $\mathrm{PKC} \alpha$ has been shown to translocate preferentially to lipid rafts $[170,171]$, and a $\mathrm{Ca}^{2+}$-dependent association of $\mathrm{PKC} \alpha$ with neurocalcin and annexin $\mathrm{A} 6$ has been observed in lipid rafts from the synaptic plasma membrane of rat brain [172]. These findings support the hypothesis that annexin A6 might act as a scaffold for PKC, thus influencing its function. 
Annexin A5 has been described as a regulator of PKC activity [173]. In Jurkat cells, annexin A5 inhibited phosphorylation of annexin $\mathrm{A} 2$ by endogenous $\mathrm{PKC}$ and phosphorylation of myelin basic protein by $\mathrm{PKC} \alpha$ [173]. PKC inhibition by annexin A5 was the consequence of phospholipid sequestration, and the $\mathrm{Ca}^{2+}$-binding site located in domain 1 of annexin A5 was shown to play a predominant role in this process. The studies in cell-free systems demonstrated the ability of annexin A5 to inhibit the PKC-catalyzed phosphorylation in the presence or absence of its activator 12-o-tetradecanoylphorbol-13acetate (TPA) [174, 175]. Overexpression of annexin A5 in breast cancer MCF-7 cells resulted in an inhibition of TPA-induced Ras/ERK signaling via inhibition of PKC, possibly $\mathrm{PKC} \delta$, but the exact mechanism of its action has not been elucidated [176].

Recent studies link the function of PKC to the amount of PtdIns $_{4,5} \mathrm{P}_{2}$ in the plasma membrane [177, 178]. An increase in the PtdIns ${ }_{4,5} \mathrm{P}_{2}$ concentration prolongs the presence of $\mathrm{PKC} \alpha$ within the plasma membrane when PC12 cells were stimulated with ATP, independently of the DAG generated. When the magnitude of $\mathrm{PtdIns}_{4,5} \mathrm{P}_{2}$ binding was compared with that of other polyphosphate phosphatidylinositols, it was seen to be greater in both $\operatorname{PKC} \beta$ - and PKC $\gamma-\mathrm{C} 2$ domains. The concentration of $\mathrm{Ca}^{2+}$ required to bind to membranes was lower in the presence of PtdIns $_{4,5} \mathrm{P}_{2}$ for all $\mathrm{C} 2$ domains, especially for $\mathrm{PKC} \alpha$. Considering the preferential binding of annexins $\mathrm{A} 2$ and A8 to PtdIns ${ }_{4,5} \mathrm{P}_{2}$ (see above), one might envisage a regulatory cross-roads in the function of these protein families.

\section{Regulation of Ras}

The activation of Ras occurs downstream of many cell surface receptors, including receptor protein kinases, and the Ras/Raf/MAPK pathway serves as a link between the signalling cascades regulating cell growth, differentiation, and survival. The Ras GTPases are resident at the inner leaflet of the plasma membrane and function as molecular switches, shuttling between an inactive Ras-GDP and an active Ras-GTP [179]. The GTP/GDP exchange rate is regulated by nucleotide exchange factors (GEFs) and GTPase activating proteins (GAPs) [180, 181]. Earlier studies established the existence of a specific interaction between annexin A6 and p120GAP [182, 183] and showed that this binding was $\mathrm{Ca}^{2+}$-independent and required amino acids 325-363 of annexin A6, localized in the inter-lobe linker region of the protein. Since this binding site does not interfere with the $\mathrm{Ca}^{2+}$-dependent interaction of annexin A6 with the plasma membrane, it might facilitate the membrane binding of p120GAP, and indeed it was shown that annexin A6 inactivated Ras by recruiting p120GAP to the plasma membrane [184, 185]. In CHO cells, the elevation of $\mathrm{Ca}^{2+}$ following an activation of growth factor receptors promoted a membrane association of the annexin A6-p120GAP complex and consequently a reduction of EGF-induced activation of Ras and Raf-1.

Overexpression of epidermal growth factor receptor (EGFR) is associated with enhanced activation of wildtype (hyperactive) Ras in breast cancer [186]. Recently it was shown that annexin A6 was down-regulated in a number of EGFR-overexpressing and estrogen receptornegative breast cancer cells [186]. In these cells, the restored expression of annexin A6 promoted $\mathrm{Ca}^{2+}$ - and EGF-inducible membrane targeting of p120GAP. The $\mathrm{Ca}^{2+}$ - and EGF-inducible complex of annexin A6 with $\mathrm{H}-$ Ras was detected by co-immunoprecipitation from the cell lysates of these cells, and FRET microscopy confirmed the close proximity of annexin A6 and the active $(\mathrm{G} 12 \mathrm{~V})$, but not inactive $(\mathrm{S} 17 \mathrm{~N}) \mathrm{H}-\mathrm{Ras}$ [186]. Interestingly, the expression of annexin A6 is reduced or lost in many cancers [187], which might have a bearing for cancer progression. It is likely that the tumor-suppressing activity of annexin A6 is linked to its ability to cause the downregulation of the cell proliferation pathways initiated by activated Ras.

\section{Annexins and intracellular stress}

Membrane interaction upon hypoxia-induced intracellular acidification

The intracellular $\mathrm{pH}\left(\mathrm{pH}_{\mathrm{i}}\right)$ is an important physiological parameter, and several proteins have the ability to interact with cellular membranes in a $\mathrm{pH}$-dependent manner, thus acting as $\mathrm{pH}$ sensors: cytochrome $\mathrm{C}, \mathrm{Bcl}-\mathrm{xL}$, and chromogranins $\mathrm{A}$ and $\mathrm{B}$ have been shown to bind lipid vesicles at acidic pH [188-190], and ARF1 is associated with endosomal membranes in a pH-dependent manner [191].

Hypoxia and ischemia are associated with a decrease in $\mathrm{pH}_{\mathrm{i}}$ : a mean $\mathrm{pH}_{\mathrm{i}}$ of 5.3 was demonstrated in hippocampal neurons [192, 193]. Subjecting the cells to hypoxia induced a robust expression of the oxygen-regulated HIF-1 subunit HIF- $1 \alpha$, observed already after $1 \mathrm{~h}$ of exposure, and a concomitant decrease in the $\mathrm{pH}_{\mathrm{i}}$ [130]. We showed that hypoxia promoted the interaction of recombinant annexin A2-S100A10 and annexin A6 with the plasma membrane: exposure to hypoxic conditions resulted in an association of annexin A6 with the plasma membrane [130]. Similarly, the annexin A2-S100A10 heterotetramer translocated to the plasma membrane after $30 \mathrm{~min}$ of hypoxia. The $\mathrm{pH}_{\mathrm{i}}$ values required for membrane association of the recombinant annexin A2-S100A10 in normal and hypoxic conditions correlate well, which indicates that it is the 
hypoxia-induced intracellular acidification and not the reduction of $\mathrm{O}_{2}$ per se that drives the interaction [130].

Intracellular $\mathrm{pH}$ values, which in resting cells are in the neutral range (7.0-7.2), can change rapidly during muscle contraction: intramuscular $\mathrm{pH}$ declines from 7.1 to 6.5 due to skeletal-muscle fatigue [194]. Hypoxia and ischemia are accompanied by a dramatic drop in $\mathrm{pH}_{\mathrm{i}}$. This decrease probably results from immediate blockade of oxidative phosphorylation and activation of glycolysis [195]. An important consequence of intracellular acidification in neurons is the $\mathrm{Ca}^{2+}$-dependent increase in neurotransmitter release [196]. In the heart, an ischemia-induced decrease in $\mathrm{pH}_{\mathrm{i}}$ from 7.4 to 6.7 has recently been shown to activate the acid-sensing ion channels (ASICS) in the sensory neurons and contribute to the sensation of angina [197]. Interestingly, hypoxia induced the expression of annexins A2 and A5 in the placental cell line BeWo, whereas the levels of antioxidants and some cytoskeletal proteins were reduced [198]. Similarly, hypoxia induced the expression of annexin A2 in cultured human cervical epithelial cells [199]. The annexin A2-S100A10 complex, shown to regulate ASICS1 [166] under normal conditions, might therefore have an additional function during hypoxic stress, thus indirectly contributing to the regulation of $\mathrm{pH}$-induced ion channel activity. Alternatively, annexin A6, recruited to the plasma membrane by a decrease in $\mathrm{pH}_{\mathrm{i}}$, might influence the $\mathrm{pH}$ homeostasis through its interaction with $\mathrm{PKC}$, a known regulator of the activity of the NHE1 proton exchanger.

\section{Cellular stress and membrane repair}

Hypoxia, osmotic and heat shock, oxidative stress, and local membrane damage result in the activation of multiple intracellular signaling pathways, accompanied by changes in $\left[\mathrm{Ca}^{2+}\right]_{i}$ and leading ultimately to adaptive changes in gene expression. Oxidative stress has been shown to affect expression and localization of different annexins. In earlier publications, annexin A2 was identified as an oxidantsensitive protein, based on a screen of transient incorporation of glutathione into cellular proteins [200]. Glutathionylation inhibited the membrane-binding activity of annexin A2 and might represent a regulatory mechanism influencing its function at the plasma membrane [201]. In contrast, annexin A5 was shown to associate $\mathrm{Ca}^{2+}$-independently with phospholipid vesicles in vitro at $\mathrm{pH} 7.4$, in the presence of $3 \mathrm{mM} \mathrm{H} \mathrm{H}_{2} \mathrm{O}_{2}$ [202]. The expression and localization of annexins was investigated in chronically hyperoxically stressed endothelial cells [203]. In this study, annexin expression levels did not change significantly in response to hyperoxic stress, but immunofluorescence analysis revealed striking effects on the subcellular localization of certain annexins, including the redistribution of annexins A5 and A6 from the cytosol to the nucleus.
Annexins have been implicated in the regulation of repair mechanisms on both tissue and intracellular levels. Annexin A2 was implicated in wound closure in several studies. Patchell et al. [204] examined the role of glycosylation and expression of glycoproteins after epithelial injury and demonstrated that following injury, N-glycosylation events and annexin A2 presentation on the cell surface of airway epithelial cells are important mediators in repair [204]. Following mechanical wounding of confluent monolayers of human airway epithelial cells, glycosylation staining increased on the cell surface of groups of cells in the proximity of the wound edge. By membrane protein biotinylation and immunodetection, the authors have shown that following mechanical wounding, the presentation of annexin A2 on the cell surface increased coordinately with repair. Babbin et al. [205] observed that gastrointestinal mucosal wound healing is dependent on actin cytoskeletal reorganization and that there is an increased expression of annexin A2 in migrating intestinal epithelial cells. The authors used siRNA-mediated inhibition of annexin A2 expression and observed Rho dissociation from membranes and decreased Rho activity following annexin A2 siRNA transfection. Annexin A2 was observed to co-immunoprecipitate with endogenous Rho and constitutively active RhoA. These findings suggest that annexin A2 plays a role in targeting Rho to cellular membranes during epithelial cell migration and tissue repair [205].

Annexin A1 also has an important function in intracellular repair and tissue regeneration mechanisms. Using annexin A1-knockout mice, Babbin et al. [206] demonstrated the role of this annexin in the regulation of intestinal mucosal injury and repair: annexin A1-deficient animals exhibited an increased susceptibility to dextran sulfate sodium-induced colitis with greater clinical morbidity and histopathologically visible mucosal injury [206]. At the intracellular level, both annexins A1 and A2 were shown to interact with dysferlin in a $\mathrm{Ca}^{2+}$ - and membraneinjury-dependent manner [207]. The distribution of the annexins and the efficiency of sarcolemmal wound-healing are significantly disrupted in dysferlin-deficient muscle, suggesting an important role of annexins in sarcolemmal repair through mediating membrane fusion.

McNeil et al. [208] established a role of annexin A1 in membrane repair. They showed that $\mathrm{Ca}^{2+}$ entering a cell through a damaged plasma membrane rapidly triggers membrane fusion events, resulting in the assembly of a reparative membrane patch at the defect site. An annexin A1 function-blocking antibody, a small peptide competitor, and a dominant-negative annexin A1 mutant protein incapable of $\mathrm{Ca}^{2+}$ binding, all inhibited resealing. Coincident with a resealing event, annexin A1 was observed to concentrate at disruption sites. The authors propose that $\mathrm{Ca}^{2+}$ 
entry through a disruption locally induces annexin A1 binding to membranes, initiating emergency fusion events whenever and wherever required.

Annexins as diagnostic tools for human disease

Although there is no direct evidence implicating any individual member of the annexin family as a diseasecausing gene, in certain clinical conditions, changes in annexin expression levels or localization may contribute to the progression of disease. In this way, annexins are indirectly linked to some of the most serious human pathologies including cardiovascular disease and cancer [41, 209]. Despite a wealth of experimental data, in the case of these "annexinopathies," the translation of scientific results into therapeutic concepts is still in its infancy.

In the meantime, the importance of annexins as diagnostic tools is becoming increasingly recognized. Coupled to thrombolytic enzymes, annexin A5 has localized intravascular thrombi [210]. Technetium-labeled annexin A5 has been used as a marker for apoptotic cells in cardiovascular medicine [211], and its specific binding to phosphatidylserine has made this protein a potential candidate for predicting the effectiveness of cancer chemotherapy [212]. Annexin A1, which has been credited with anti-inflammatory properties [213], is thought to contribute to the resolution of an inflammatory response by the removal of extravasated neutrophils [214]. Therefore the ability of annexins to respond to disease- and stressrelated alterations of the cellular environment and restore the intracellular homeostasis makes this protein family an important group of diagnostic and therapeutic targets.

\section{Conclusions}

A chronic stress response triggers the activation of different intracellular pathways, resulting in profound changes in $\mathrm{Ca}^{2+}$ and $\mathrm{pH}$ homeostasis, production of lipid second messengers such as $\operatorname{PtdIns}_{4,5} \mathrm{P}_{2}$, DAG, and ceramide, and an alteration of membrane curvature caused by clustering of specific lipids. These changes are sensed by the members of the annexin protein family, which have the ability to interact with specific lipid moieties at the plasma membrane and simultaneously associate with various signaling proteins.

Indeed, annexins act as sensors for $\left[\mathrm{Ca}^{2+}\right]_{\mathrm{i}}$. They interact with the plasma membrane and other cellular membranes in a coordinated, $\mathrm{Ca}^{2+}$-dependent manner. The $\mathrm{Ca}^{2+}$ sensitivity of annexin-membrane binding is affected and modulated by interaction with other proteins and proteolytic cleavage, and several annexins present within any one cell form a broad-range $\left[\mathrm{Ca}^{2+}\right]_{\mathrm{i}}$-sensing system.
Additionally, annexins respond to $\mathrm{pH}_{\mathrm{i}}$ decrease, and specifically annexins A6 and A2-S100A10 act as pH sensors by interacting with the plasma membrane of living cells upon a decrease in $\mathrm{pH}_{\mathrm{i}}$ to 6.6 and 6.8. The $\mathrm{pH}$-induced membrane interaction of annexins is $\mathrm{Ca}^{2+}$-independent and, together with the ability of annexins to sense changes in membrane curvature, represents an important alternative mechanism of membrane binding.

Intracellular acidification, oxidative stress, and a concomitant increase in $\left[\mathrm{Ca}^{2+}\right]_{i}$ promote membrane binding of annexins, which have distinct preferences as to the proteins and lipids with which they interact. Annexins A1, A2, and A6 act as sensors for lipid second messengers ceramide, PtdIns $_{4,5} \mathrm{P}_{2}\left(\mathrm{PIP}_{2}\right)$, and DAG. Upon membrane binding, annexins regulate various signaling pathways, including the activation of PKC and Ras, and regulate $\mathrm{Ca}^{2+}$ homeostasis by affecting ion channels and $\mathrm{Ca}^{2+}$ entry. Importantly, they also affect the mechanism of intracellular membrane repair in a $\mathrm{Ca}^{2+}$-dependent manner, thus defining cell survival and proliferation under stress conditions.

The high degree of sequence conservation, and considerable functional and structural redundancy of different annexins renders them important regulators of cell signaling. Novel functions of individual members of the annexin protein family, which have recently been elucidated, show the diversity of these proteins. On the other hand, these specific functions might be executed in parallel with a more general role of annexins as watchdogs of intracellular homeostasis, contributing to cellular adaptation to stress signals.

Acknowledgments The authors gratefully acknowledge the financial support of the Swiss National Science Foundation through SNF Grant 320000-111778 to K. Monastyrskaya and SNF Grant 3100A0_121980/1 to E. B. Babiychuk and the National Research Program NRP 53 "Musculoskeletal Health-Chronic Pain" 405340$104679 / 1$ to A. Draeger. K. Monastyrskaya thanks all members of A. Draeger's lab for their continuous help and support, and Manu Chao for inspiration.

\section{References}

1. Coussens LM, Werb Z (2002) Inflammation and cancer. Nature 420:860-867

2. Austin C, Wray S (2000) Interactions between $\mathrm{Ca}(2+)$ and $\mathrm{H}(+)$ and functional consequences in vascular smooth muscle. Circ Res 86:355-363

3. Wakabayashi I, Poteser M, Groschner K (2006) Intracellular pH as a determinant of vascular smooth muscle function. J Vasc Res 43:238-250

4. Sandoval AJ, Riquelme JP, Carretta MD, Hancke JL, Hidalgo MA, Burgos RA (2007) Store-operated calcium entry mediates intracellular alkalinization, ERK1/2, and Akt/PKB phosphorylation in bovine neutrophils. J Leukoc Biol 82:1266-1277

5. Lui KE, Panchal AS, Santhanagopal A, Dixon SJ, Bernier SM (2002) Epidermal growth factor stimulates proton efflux from chondrocytic cells. J Cell Physiol 192:102-112 
6. Berridge MJ, Lipp P, Bootman MD (2000) The versatility and universality of calcium signalling. Nat Rev Mol Cell Biol $1: 11-21$

7. Gerke V, Moss SE (1997) Annexins and membrane dynamics. Biochim Biophys Acta Mol Cell Res 1357:129-154

8. Babiychuk EB, Draeger A (2000) Annexins in cell membrane dynamics: $\mathrm{Ca}^{2+}$-regulated association of lipid microdomains. J Cell Biol 150:1113-1123

9. Harder T, Kellner R, Parton RG, Gruenberg J (1997) Specific release of membrane-bound annexin II and cortical cytoskeletal elements by sequestration of membrane cholesterol. Mol Biol Cell 8:533-545

10. Creutz CE, Pazoles CJ, Pollard HB (1978) Identification and purification of an adrenal medullary protein (synexin) that causes calcium-dependent aggregation of isolated chromaffin granules. J Biol Chem 253:2858-2866

11. Creutz CE, Sterner DC (1983) Calcium dependence of the binding of synexin to isolated chromaffin granules. Biochem Biophys Res Commun 114:355-364

12. Huang KS, Wallner BP, Mattaliano RJ, Tizard R, Burne C, Frey A, Hession C, McGray P, Sinclair LK, Chow EP (1986) Two human $35 \mathrm{kd}$ inhibitors of phospholipase A2 are related to substrates of pp60v-src and of the epidermal growth factor receptor/kinase. Cell 46:191-199

13. Saris CJ, Tack BF, Kristensen T, Glenney JR Jr, Hunter T (1986) The cDNA sequence for the protein-tyrosine kinase substrate p36 (calpactin I heavy chain) reveals a multidomain protein with internal repeats. Cell 46:201-212

14. Saris CJ, Kristensen T, D'Eustachio P, Hicks LJ, Noonan DJ, Hunter T, Tack BF (1987) cDNA sequence and tissue distribution of the mRNA for bovine and murine p11, the S100related light chain of the protein-tyrosine kinase substrate p36 (calpactin I). J Biol Chem 262:10663-10671

15. Miwa N, Uebi T, Kawamura S (2008) S100-annexin complexesbiology of conditional association. FEBS J 275:4945-4955

16. Moss SE, Morgan RO (2004) The annexins. Genome Biol 5:219

17. Gerke V, Moss SE (2002) Annexins: from structure to function. Physiol Rev 82:331-371

18. Gerke V, Creutz CE, Moss SE (2005) Annexins: linking $\mathrm{Ca}^{2+}$ signalling to membrane dynamics. Nat Rev Mol Cell Biol 6:449-461

19. Futter CE, White IJ (2007) Annexins and endocytosis. Traffic 8:951-958

20. Concha NO, Head JF, Kaetzel MA, Dedman JR, Seaton BA (1993) Rat annexin V crystal structure: $\mathrm{Ca}(2+)$-induced conformational changes. Science 261:1321-1324

21. Luecke H, Chang BT, Mailliard WS, Schlaepfer DD, Haigler HT (1995) Crystal structure of the annexin XII hexamer and implications for bilayer insertion [see comments]. Nature 378:512-515

22. Favier-Perron B, Lewit-Bentley A, Russo-Marie F (1996) The high-resolution crystal structure of human annexin III shows subtle differences with annexin V. Biochemistry 35:1740-1744

23. Swairjo MA, Concha NO, Kaetzel MA, Dedman JR, Seaton BA (1995) Ca(2+)-bridging mechanism and phospholipid head group recognition in the membrane-binding protein annexin $\mathrm{V}$. Nat Struct Biol 2:968-974

24. Ayala-Sanmartin J, Vincent M, Sopkova J, Gallay J (2000) Modulation by $\mathrm{Ca}^{2+}$ and by membrane binding of the dynamics of domain III of annexin 2 (p36) and the annexin 2-p11 complex (p90): implications for their biochemical properties. Biochemistry 39:15179-15189

25. Rescher U, Gerke V (2008) S100A10/p11: family, friends and functions. Pflugers Arch 455:575-582

26. Ayala-Sanmartin J, Gouache P, Henry JP (2000) N-terminal domain of annexin 2 regulates $\mathrm{Ca}^{2+}$-dependent membrane aggregation by the core domain: a site directed mutagenesis study. Biochemistry 39:15190-15198

27. Sopkova J, Raguenes-Nicol C, Vincent M, Chevalier A, LewitBentley A, Russo-Marie F, Gallay J (2002) Ca(2+) and membrane binding to annexin 3 modulate the structure and dynamics of its N terminus and domain III. Protein Sci 11:1613-1625

28. Weng X, Luecke H, Song IS, Kang DS, Kim SH, Huber R (1993) Crystal structure of human annexin I at $2.5 \AA$ resolution. Protein Sci 2:448-458

29. Rosengarth A, Luecke H (2003) A calcium-driven conformational switch of the $\mathrm{N}$-terminal and core domains of annexin A1. J Mol Biol 326:1317-1325

30. Lambert O, Gerke V, Bader MF, Porte F, Brisson A (1997) Structural analysis of junctions formed between lipid membranes and several annexins by cryo-electron microscopy. J Mol Biol 272:42-55

31. Bitto E, Cho W (1999) Structural determinant of the vesicle aggregation activity of annexin I. Biochemistry 38:1409414100

32. Bitto E, Li M, Tikhonov AM, Schlossman ML, Cho W (2000) Mechanism of annexin I-mediated membrane aggregation. Biochemistry 39:13469-13477

33. Rety S, Osterloh D, Arie JP, Tabaries S, Seeman J, Russo-Marie F, Gerke V, Lewit-Bentley A (2000) Structural basis of the $\mathrm{Ca}(2+)$-dependent association between S100C (S100A11) and its target, the N-terminal part of annexin I. Structure 8:175-184

34. Avila-Sakar AJ, Kretsinger RH, Creutz CE (2000) Membranebound 3D structures reveal the intrinsic flexibility of annexin VI. J Struct Biol 130:54-62

35. Draeger A, Wray S, Babiychuk EB (2005) Domain architecture of the smooth-muscle plasma membrane: regulation by annexins. Biochem J 387:309-314

36. Camors E, Monceau V, Charlemagne D (2005) Annexins and $\mathrm{Ca} 2+$ handling in the heart. Cardiovasc Res 65:793-802

37. Raynal P, Hullin F, Ragab-Thomas JM, Fauvel J, Chap H (1993) Annexin 5 as a potential regulator of annexin 1 phosphorylation by protein kinase $C$. In vitro inhibition compared with quantitative data on annexin distribution in human endothelial cells. Biochem J 292:759-765

38. Le CV, Russo-Marie F, Maridonneau-Parini I (1992) Differential expression of two forms of annexin 3 in human neutrophils and monocytes and along their differentiation. Biochem Biophys Res Commun 189:1471-1476

39. Runkel F, Michels M, Franken S, Franz T (2006) Specific expression of annexin A8 in adult murine stratified epithelia. J Mol Histol 37:353-359

40. Iglesias JM, Morgan RO, Jenkins NA, Copeland NG, Gilbert DJ, Fernandez MP (2002) Comparative genetics and evolution of annexin A13 as the founder gene of vertebrate annexins. Mol Biol Evol 19:608-618

41. Hayes MJ, Moss SE (2004) Annexins and disease. Biochem Biophys Res Commun 322:1166-1170

42. Mussunoor S, Murray GI (2008) The role of annexins in tumour development and progression. J Pathol 216:131-140

43. Xin W, Rhodes DR, Ingold C, Chinnaiyan AM, Rubin MA (2003) Dysregulation of the annexin family protein family is associated with prostate cancer progression. Am J Pathol 162:255-261

44. Srivastava M, Torosyan Y, Raffeld M, Eidelman O, Pollard HB, Bubendorf L (2007) ANXA7 expression represents hormonerelevant tumor suppression in different cancers. Int $\mathrm{J}$ Cancer 121:2628-2636

45. Burkhard FC, Monastyrskaya K, Studer UE, Draeger A (2005) Smooth muscle membrane organization in the normal and dysfunctional human urinary bladder: a structural analysis. Neurourol Urodyn 24:128-135 
46. Merrifield CJ, Moss SE, Ballestrem C, Imhof BA, Giese G, Wunderlich I, Almers W (1999) Endocytic vesicles move at the tips of actin tails in cultured mast cells. Nat Cell Biol 1:72-74

47. Mayran N, Parton RG, Gruenberg J (2003) Annexin II regulates multivesicular endosome biogenesis in the degradation pathway of animal cells. EMBO J 22:3242-3253

48. Zobiack N, Rescher U, Ludwig C, Zeuschner D, Gerke V (2003) The annexin 2/S100A10 complex controls the distribution of transferrin receptor-containing recycling endosomes. Mol Biol Cell 14:4896-4908

49. Diakonova M, Gerke V, Ernst J, Liautard JP, van der Vusse G, Griffiths G (1997) Localization of five annexins in J774 macrophages and on isolated phagosomes. J Cell Sci 110:1199-1213

50. Rambotti MG, Spreca A, Donato R (1993) Immunocytochemical localization of annexins V and VI in human placentae of different gestational ages. Cell Mol Biol Res 39:579-588

51. Barwise JL, Walker JH (1996) Subcellular localization of annexin $\mathrm{V}$ in human foreskin fibroblasts: nuclear localization depends on growth state. FEBS Lett 394:213-216

52. Mohiti J, Caswell AM, Walker JH (1997) The nuclear location of annexin $\mathrm{V}$ in the human osteosarcoma cell line MG-63 depends on serum factors and tyrosine kinase signaling pathways. Exp Cell Res 234:98-104

53. Raynal P, Pollard HB (1994) Annexins: the problem of assessing the biological role for a gene family of multifunctional calciumand phospholipid-binding proteins. Biochim Biophys Acta 1197:63-93

54. Junker M, Creutz CE (1994) $\mathrm{Ca}(2+)$-dependent binding of endonexin (annexin IV) to membranes: analysis of the effects of membrane lipid composition and development of a predictive model for the binding interaction. Biochemistry 33:8930-8940

55. Eberhard DA, Vandenberg SR (1998) Annexins I and II bind to lipid A: a possible role in the inhibition of endotoxins. Biochem J 330:67-72

56. Gamper N, Shapiro MS (2007) Target-specific PIP(2) signalling: how might it work? J Physiol 582:967-975

57. Berridge MJ (1987) Inositol trisphosphate and diacylglycerol: two interacting second messengers. Annu Rev Biochem 56:159-193

58. Mao YS, Yin HL (2007) Regulation of the actin cytoskeleton by phosphatidylinositol 4-phosphate 5 kinases. Pflugers Arch 455:5-18

59. Hayes MJ, Merrifield CJ, Shao D, Ayala-Sanmartin J, Schorey CD, Levine TP, Proust J, Curran J, Bailly M, Moss SE (2004) Annexin 2 binding to phosphatidylinositol 4,5-bisphosphate on endocytic vesicles is regulated by the stress response pathway. J Biol Chem 279:14157-14164

60. Rescher U, Ruhe D, Ludwig C, Zobiack N, Gerke V (2004) Annexin 2 is a phosphatidylinositol $(4,5)$-bisphosphate binding protein recruited to actin assembly sites at cellular membranes. J Cell Sci 117:3473-3480

61. Zobiack N, Rescher U, Laarmann S, Michgehl S, Schmidt MA, Gerke V (2002) Cell-surface attachment of pedestal-forming enteropathogenic $E$. coli induces a clustering of raft components and a recruitment of annexin 2. J Cell Sci 115:91-98

62. Jost M, Zeuschner D, Seemann J, Weber K, Gerke V (1997) Identification and characterization of a novel type of annexinmembrane interaction: $\mathrm{Ca}^{2+}$ is not required for the association of annexin II with early endosomes. J Cell Sci 110:221-228

63. Zeuschner D, Stoorvogel W, Gerke V (2001) Association of annexin 2 with recycling endosomes requires either calcium- or cholesterol-stabilized membrane domains. Eur J Cell Biol 80:499-507

64. Uittenbogaard A, Everson WV, Matveev SV, Smart EJ (2002) Cholesteryl ester is transported from caveolae to internal membranes as part of a caveolin-annexin II lipid-protein complex. J Biol Chem 277:4925-4931

65. Smart EJ, De Rose RA, Farber SA (2004) Annexin 2-caveolin 1 complex is a target of ezetimibe and regulates intestinal cholesterol transport. Proc Natl Acad Sci USA 101:3450-3455

66. Chasserot-Golaz S, Vitale N, Sagot I, Delouche B, Dirrig S, Pradel LA, Henry JP, Aunis D, Bader MF (1996) Annexin II in exocytosis: catecholamine secretion requires the translocation of p36 to the subplasmalemmal region in chromaffin cells. J Cell Biol 133:1217-1236

67. Chasserot-Golaz S, Vitale N, Umbrecht-Jenck E, Knight D, Gerke V, Bader MF (2005) Annexin 2 promotes the formation of lipid microdomains required for calcium-regulated exocytosis of dense-core vesicles. Mol Biol Cell 16:1108-1119

68. Yamada A, Irie K, Hirota T, Ooshio T, Fukuhara A, Takai Y (2005) Involvement of the annexin II-S100A10 complex in the formation of E-cadherin-based adherens junctions in MadinDarby canine kidney cells. J Biol Chem 280:6016-6027

69. Ayala-Sanmartin J, Henry JP, Pradel LA (2001) Cholesterol regulates membrane binding and aggregation by annexin 2 at submicromolar $\mathrm{Ca}(2+)$ concentration. Biochim Biophys Acta 1510:18-28

70. Ayala-Sanmartin J (2001) Cholesterol enhances phospholipid binding and aggregation of annexins by their core domain. Biochem Biophys Res Commun 283:72-79

71. Grewal T, Heeren J, Mewawala D, Schnitgerhans T, Wendt D, Salomon G, Enrich C, Beisiegel U, Jackle S (2000) Annexin VI stimulates endocytosis and is involved in the trafficking of low density lipoprotein to the prelysosomal compartment. J Biol Chem 275:33806-33813

72. de Diego I, Schwartz F, Siegfried H, Dauterstedt P, Heeren J, Beisiegel U, Enrich C, Grewal T (2002) Cholesterol modulates the membrane binding and intracellular distribution of annexin 6. J Biol Chem 277:32187-32194

73. Cubells L, de Vila M, Tebar F, Wood P, Evans R, IngelmoTorres M, Calvo M, Gaus K, Pol A, Grewal T, Enrich C (2007) Annexin A6-induced alterations in cholesterol transport and caveolin export from the Golgi complex. Traffic 8:1568-1589

74. Brown DA, London E (1998) Functions of lipid rafts in biological membranes. Annu Rev Cell Dev Biol 14:111-136

75. Simons K, Ikonen E (1997) Functional rafts in cell membranes. Nature 387:569-572

76. Simons K, Toomre D (2000) Lipid rafts and signal transduction. Nat Rev Mol Cell Biol 1:31-39

77. Lafont F, Lecat S, Verkade P, Simons K (1998) Annexin XIIIb associates with lipid microdomains to function in apical delivery. J Cell Biol 142:1413-1427

78. Oliferenko S, Paiha K, Harder T, Gerke V, Schwarzler C, Schwarz H, Beug H, Gunthert U, Huber LA (1999) Analysis of CD44-containing lipid rafts: recruitment of annexin II and stabilization by the actin cytoskeleton. J Cell Biol 146:843-854

79. Babiychuk EB, Draeger A (2006) Biochemical characterization of detergent-resistant membranes: a systematic approach. Biochem J 397:407-416

80. Junker M, Creutz CE (1993) Endonexin (annexin IV)-mediated lateral segregation of phosphatidylglycerol in phosphatidylglycerol/phosphatidylcholine membranes. Biochemistry 32:99689974

81. Menke M, Gerke V, Steinem C (2005) Phosphatidylserine membrane domain clustering induced by annexin A2/S100A10 heterotetramer. Biochemistry 44:15296-15303

82. Babiychuk EB, Monastyrskaya K, Burkhard FC, Wray S, Draeger A (2002) Modulating signaling events in smooth muscle: cleavage of annexin 2 abolishes its binding to lipid rafts. FASEB J 16:1177-1184 
83. Draeger A, Monastyrskaya K, Burkhard FC, Wobus AM, Moss SE, Babiychuk EB (2003) Membrane segregation and downregulation of raft markers during sarcolemmal differentiation in skeletal muscle cells. Dev Biol 262:324-334

84. Monastyrskaya K, Babiychuk EB, Schittny JC, Rescher U, Gerke V, Mannherz HG, Draeger A (2003) The expression levels of three raft-associated molecules in cultivated vascular cells are dependent on culture conditions. Cell Mol Life Sci 60:2702-2709

85. Matschke K, Babiychuk EB, Monastyrskaya K, Draeger A (2006) Phenotypic conversion leads to structural and functional changes of smooth muscle sarcolemma. Exp Cell Res 312:3495-3503

86. Babiychuk EB, Monastyrskaya K, Draeger A (2008) Fluorescent annexin A1 reveals dynamics of ceramide platforms in living cells. Traffic 9:1757-1775

87. Cutler RG, Mattson MP (2001) Sphingomyelin and ceramide as regulators of development and lifespan. Mech Ageing Dev 122:895-908

88. Hannun YA, Obeid LM (2002) The ceramide-centric universe of lipid-mediated cell regulation: stress encounters of the lipid kind. J Biol Chem 277:25847-25850

89. Zheng W, Kollmeyer J, Symolon H, Momin A, Munter E, Wang E, Kelly S, Allegood JC, Liu Y, Peng Q, Ramaraju H, Sullards MC, Cabot M, Merrill AH Jr (2006) Ceramides and other bioactive sphingolipid backbones in health and disease: lipidomic analysis, metabolism and roles in membrane structure, dynamics, signaling and autophagy. Biochim Biophys Acta 1758:1864-1884

90. Kolesnick RN, Goni FM, Alonso A (2000) Compartmentalization of ceramide signaling: physical foundations and biological effects. J Cell Physiol 184:285-300

91. van Blitterswijk WJ, van der Luit AH, Veldman RJ, Verheij M, Borst J (2003) Ceramide: second messenger or modulator of membrane structure and dynamics? Biochem J 369:199-211

92. Solito E, Mulla A, Morris JF, Christian HC, Flower RJ, Buckingham JC (2003) Dexamethasone induces rapid serinephosphorylation and membrane translocation of annexin 1 in a human folliculostellate cell line via a novel nongenomic mechanism involving the glucocorticoid receptor, protein kinase $\mathrm{C}$, phosphatidylinositol 3-kinase, and mitogen-activated protein kinase. Endocrinology 144:1164-1174

93. Croxtall JD, Gilroy DW, Solito E, Choudhury Q, Ward BJ, Buckingham JC, Flower RJ (2003) Attenuation of glucocorticoid functions in an Anx-A1 ${ }^{-1-}$ cell line. Biochem $\mathrm{J}$ 371:927-935

94. Solito E, Kamal A, Russo-Marie F, Buckingham JC, Marullo S, Perretti M (2003) A novel calcium-dependent proapoptotic effect of annexin 1 on human neutrophils. FASEB J 17:15441546

95. Scannell M, Flanagan MB, de Stefani A, Wynne KJ, Cagney G, Godson C, Maderna P (2007) Annexin-1 and peptide derivatives are released by apoptotic cells and stimulate phagocytosis of apoptotic neutrophils by macrophages. J Immunol 178:4595-4605

96. Freites JA, Ali S, Rosengarth A, Luecke H, Dennin MB (2004) Annexin A1 interaction with a zwitterionic phospholipid monolayer: a fluorescence microscopy study. Langmuir 20:11674-11683

97. McMahon HT, Gallop JL (2005) Membrane curvature and mechanisms of dynamic cell membrane remodelling. Nature 438:590-596

98. Drin G, Casella JF, Gautier R, Boehmer T, Schwartz TU, Antonny B (2007) A general amphipathic alpha-helical motif for sensing membrane curvature. Nat Struct Mol Biol 14:138-146
99. Fischer T, Lu L, Haigler HT, Langen R (2007) Annexin B12 is a sensor of membrane curvature and undergoes major curvaturedependent structural changes. J Biol Chem 282:9996-10004

100. Slater SJ, Kelly MB, Taddeo FJ, Ho C, Rubin E, Stubbs CD (1994) The modulation of protein kinase C activity by membrane lipid bilayer structure. J Biol Chem 269:4866-4871

101. Ho C, Slater SJ, Stagliano B, Stubbs CD (2001) The C1 domain of protein kinase $\mathrm{C}$ as a lipid bilayer surface sensing module. Biochemistry 40:10334-10341

102. Hayes MJ, Rescher U, Gerke V, Moss SE (2004) Annexin-actin interactions. Traffic 5:571-576

103. Filipenko NR, Waisman DM (2001) The C terminus of annexin II mediates binding to F-actin. J Biol Chem 276:5310-5315

104. Tatenhorst L, Rescher U, Gerke V, Paulus W (2006) Knockdown of annexin 2 decreases migration of human glioma cells in vitro. Neuropathol Appl Neurobiol 32:271-277

105. Merrifield CJ, Rescher U, Almers W, Proust J, Gerke V, Sechi AS, Moss SE (2001) Annexin 2 has an essential role in actinbased macropinocytic rocketing. Curr Biol 11:1136-1141

106. Hayes MJ, Shao D, Bailly M, Moss SE (2006) Regulation of actin dynamics by annexin 2. EMBO J 25:1816-1826

107. Benaud C, Gentil BJ, Assard N, Court M, Garin J, Delphin C, Baudier J (2004) AHNAK interaction with the annexin 2/S100A10 complex regulates cell membrane cytoarchitecture. J Cell Biol 164:133-144

108. Goebeler V, Ruhe D, Gerke V, Rescher U (2006) Annexin A8 displays unique phospholipid and F-actin binding properties. FEBS Lett 580:2430-2434

109. Goebeler V, Poeter M, Zeuschner D, Gerke V, Rescher U (2008) Annexin A8 regulates late endosome organization and function. Mol Biol Cell 19:5267-5278

110. Kamal A, Ying YS, Anderson RGW (1998) Annexin VI-mediated loss of spectrin during coated pit budding is coupled to delivery of LDL to lysosomes. J Cell Biol 142:937-947

111. Babiychuk EB, Palstra RJ, Schaller J, Kampfer U, Draeger A (1999) Annexin VI participates in the formation of a reversible, membrane-cytoskeleton complex in smooth muscle cells. J Biol Chem 274:35191-35195

112. Babiychuk EB, Babiychuk VS, Danilova VM, Tregubov VS, Sagach VF, Draeger A (2002) Stress fibres-a $\mathrm{Ca}^{2+}$-independent store for annexins? Biochim Biophys Acta 1600:154-161

113. Locate S, Colyer J, Gawler DJ, Walker JH (2008) Annexin A6 at the cardiac myocyte sarcolemma - evidence for self-association and binding to actin. Cell Biol Int 32:1388-1396

114. Tzima E, Trotter PJ, Orchard MA, Walker JH (2000) Annexin V relocates to the platelet cytoskeleton upon activation and binds to a specific isoform of actin. Eur J Biochem 267:4720-4730

115. Regnouf F, Rendon A, Pradel LA (1991) Biochemical characterization of annexins I and II isolated from pig nervous tissue. J Neurochem 56:1985-1996

116. Alvarez-Martinez MT, Mani JC, Porte F, Faivre-Sarrailh C, Liautard JP, Sri WJ (1996) Characterization of the interaction between annexin I and profilin. Eur J Biochem 238:777-784

117. Alvarez-Martinez MT, Porte F, Liautard JP, Sri WJ (1997) Effects of profilin-annexin I association on some properties of both profilin and annexin I: modification of the inhibitory activity of profilin on actin polymerization and inhibition of the self-association of annexin I and its interactions with liposomes. Biochim Biophys Acta 1339:331-340

118. Ghitescu LD, Gugliucci A, Dumas F (2001) Actin and annexins I and II are among the main endothelial plasmalemma-associated proteins forming early glucose adducts in experimental diabetes. Diabetes 50:1666-1674

119. Movitz C, Dahlgren C (2000) Endogenous cleavage of annexin I generates a truncated protein with a reduced calcium 
requirement for binding to neutrophil secretory vesicles and plasma membrane. Biochim Biophys Acta 1468:231-238

120. Blackwood RA, Ernst JD (1990) Characterization of Ca2(+)dependent phospholipid binding, vesicle aggregation and membrane fusion by annexins. Biochem J 266:195-200

121. Monastyrskaya K, Babiychuk EB, Hostettler A, Rescher U, Draeger A (2007) Annexins as intracellular calcium sensors. Cell Calcium 41:207-219

122. Marin-Vicente C, Gomez-Fernandez JC, Corbalan-Garcia S (2005) The ATP-dependent membrane localization of protein kinase Calpha is regulated by $\mathrm{Ca}^{2+}$ influx and phosphatidylinositol 4, 5-bisphosphate in differentiated PC12 cells. Mol Biol Cell 16:2848-2861

123. Skrahina T, Piljic A, Schultz C (2008) Heterogeneity and timing of translocation and membrane-mediated assembly of different annexins. Exp Cell Res 314:1039-1047

124. Golczak M, Kicinska A, Bandorowicz-Pikula J, Buchet R, Szewczyk A, Pikula S (2001) Acidic pH-induced folding of annexin VI is a prerequisite for its insertion into lipid bilayers and formation of ion channels by the protein molecules. FASEB J 15:1083-1085

125. Kim YE, Isas JM, Haigler HT, Langen R (2005) A helical hairpin region of soluble annexin B12 refolds and forms a continuous transmembrane helix at mildly acidic $\mathrm{pH}$. J Biol Chem 280:32398-32404

126. Kohler G, Hering U, Zschornig O, Arnold K (1997) Annexin V interaction with phosphatidylserine-containing vesicles at low and neutral $\mathrm{pH}$. Biochemistry 36:8189-8194

127. Isas JM, Cartailler JP, Sokolov Y, Patel DR, Langen R, Luecke H, Hall JE, Haigler HT (2000) Annexins V and XII insert into bilayers at mildly acidic $\mathrm{pH}$ and form ion channels. Biochemistry 39:3015-3022

128. Hegde BG, Isas JM, Zampighi G, Haigler HT, Langen R (2006) A novel calcium-independent peripheral membrane-bound form of annexin B12. Biochemistry 45:934-942

129. Golczak M, Kirilenko A, Bandorowicz-Pikula J, Pikula S (2001) Conformational states of annexin VI in solution induced by acidic pH. FEBS Lett 496:49-54

130. Monastyrskaya K, Tschumi F, Babiychuk EB, Stroka D, Draeger A (2008) Annexins sense changes in intracellular $\mathrm{pH}$ during hypoxia. Biochem J 409:65-75

131. Hoekstra D, Buist-Arkema R, Klappe K, Reutelingsperger CP (1993) Interaction of annexins with membranes: the N-terminus as a governing parameter as revealed with a chimeric annexin. Biochemistry 32:14194-14202

132. Langen R, Isas JM, Luecke H, Haigler HT, Hubbell WL (1998) Membrane-mediated assembly of annexins studied by sitedirected spin labeling. J Biol Chem 273:22453-22457

133. Strzelecka-Kiliszek A, Buszewska ME, Podszywalow-Bartnicka P, Pikula S, Otulak K, Buchet R, Bandorowicz-Pikula J (2008) Calcium- and pH-dependent localization of annexin A6 isoforms in Balb/3T3 fibroblasts reflecting their potential participation in vesicular transport. J Cell Biochem 104:418434

134. Lambert O, Cavusoglu N, Gallay J, Vincent M, Rigaud JL, Henry JP, Ayala-Sanmartin J (2004) Novel organization and properties of annexin 2-membrane complexes. J Biol Chem 279:10872-10882

135. Zibouche M, Vincent M, Illien F, Gallay J, Ayala-Sanmartin J (2008) The N-terminal domain of annexin 2 serves as a secondary binding site during membrane bridging. J Biol Chem 283:22121-22127

136. Burger A, Voges D, Demange P, Perez CR, Huber R, Berendes $R$ (1994) Structural and electrophysiological analysis of annexin $\mathrm{V}$ mutants. Mutagenesis of human annexin $\mathrm{V}$, an in vitro voltage-gated calcium channel, provides information about the structural features of the ion pathway, the voltage sensor and the ion selectivity filter. J Mol Biol 237:479-499

137. Burger A, Berendes R, Liemann S, Benz J, Hofmann A, Gottig P, Huber R, Gerke V, Thiel C, Romisch J, Weber K (1996) The crystal structure and ion channel activity of human annexin II, a peripheral membrane protein. J Mol Biol 257:839-847

138. Cohen BE, Lee G, Arispe N, Pollard HB (1995) Cyclic 3'-5'adenosine monophosphate binds to annexin I and regulates calcium-dependent membrane aggregation and ion channel activity. FEBS Lett 377:444-450

139. Kourie JI, Wood HB (2000) Biophysical and molecular properties of annexin-formed channels. Prog Biophys Mol Biol 73:91-134

140. Langen R, Isas JM, Hubbell WL, Haigler HT (1998) A transmembrane form of annexin XII detected by site-directed spin labeling. Proc Natl Acad Sci USA 95:14060-14065

141. Diaz-Munoz M, Hamilton SL, Kaetzel MA, Hazarika P, Dedman JR (1990) Modulation of $\mathrm{Ca}^{2+}$ release channel activity from sarcoplasmic reticulum by annexin VI $(67-\mathrm{kDa}$ calcimedin). J Biol Chem 265:15894-15899

142. Naciff JM, Behbehani MM, Kaetzel MA, Dedman JR (1996) Annexin VI modulates $\mathrm{Ca}^{2+}$ and $\mathrm{K}^{+}$conductances of spinal cord and dorsal root ganglion neurons. Am J Physiol 271:C2004-C2015

143. Camors E, Charue D, Trouve P, Monceau V, Loyer X, RussoMarie F, Charlemagne D (2006) Association of annexin A5 with $\mathrm{Na}^{+} / \mathrm{Ca}^{2+}$ exchanger and caveolin-3 in non-failing and failing human heart. J Mol Cell Cardiol 40:47-55

144. Gunteski-Hamblin AM, Song G, Walsh RA, Frenzke M, Boivin GP, Dorn GW, Kaetzel MA, Horseman ND, Dedman JR (1996) Annexin VI overexpression targeted to heart alters cardiomyocyte function in transgenic mice. Am J Physiol 270:H1091H1100

145. Song G, Harding SE, Duchen MR, Tunwell R, O'Gara P, Hawkins TE, Moss SE (2002) Altered mechanical properties and intracellular calcium signaling in cardiomyocytes from annexin 6 null-mutant mice. FASEB J 16:622-624

146. Fleet A, Ashworth R, Kubista H, Edwards H, Bolsover S, Mobbs P, Moss SE (1999) Inhibition of EGF-dependent calcium influx by annexin VI is splice form-specific. Biochem Biophys Res Commun 260:540-546

147. Parekh AB (2006) On the activation mechanism of store-operated calcium channels. Pflugers Arch 453:303-311

148. Vig M, Peinelt C, Beck A, Koomoa DL, Rabah D, KoblanHuberson M, Kraft S, Turner H, Fleig A, Penner R, Kinet JP (2006) CRACM1 is a plasma membrane protein essential for store-operated $\mathrm{Ca}^{2+}$ entry. Science 312:1220-1223

149. Putney JW Jr (2005) Capacitative calcium entry: sensing the calcium stores. J Cell Biol 169:381-382

150. Soboloff J, Spassova MA, Dziadek MA, Gill DL (2006) Calcium signals mediated by STIM and Orai proteins - a new paradigm in inter-organelle communication. Biochim Biophys Acta 1763:1161-1168

151. Patterson RL, van Rossum DB, Gill DL (1999) Store-operated $\mathrm{Ca}^{2+}$ entry: evidence for a secretion-like coupling model. Cell 98:487-499

152. Rosado JA, Sage SO (2000) The actin cytoskeleton in storemediated calcium entry. J Physiol 526:221-229

153. Jardin I, Lopez JJ, Salido GM, Rosado JA (2008) Orai1 mediates the interaction between STIM1 and hTRPC1 and regulates the mode of activation of hTRPC1-forming $\mathrm{Ca}^{2+}$ channels. J Biol Chem 283:25296-25304

154. Hawkins TE, Merrifield CJ, Moss SE (2000) Calcium signaling and annexins. Cell Biochem Biophys 33:275-296

155. Kaetzel MA, Chan HC, Dubinsky WP, Dedman JR, Nelson DJ (1994) A role for annexin IV in epithelial cell function. 
Inhibition of calcium-activated chloride conductance. J Biol Chem 269:5297-5302

156. Nilius B, Gerke V, Prenen J, Szucs G, Heinke S, Weber K, Droogmans G (1996) Annexin II modulates volume-activated chloride currents in vascular endothelial cells. J Biol Chem 271:30631-30636

157. Vennekens R, Hoenderop JG, Prenen J, Stuiver M, Willems PH, Droogmans G, Nilius B, Bindels RJ (2000) Permeation and gating properties of the novel epithelial $\mathrm{Ca}(2+)$ channel. J Biol Chem 275:3963-3969

158. van de Graaf SF, Hoenderop JG, Bindels RJ (2006) Regulation of TRPV5 and TRPV6 by associated proteins. Am J Physiol Renal Physiol 290:F1295-F1302

159. van de Graaf SF, Hoenderop JG, Gkika D, Lamers D, Prenen J, Rescher U, Gerke V, Staub O, Nilius B, Bindels RJ (2003) Functional expression of the epithelial $\mathrm{Ca}(2+)$ channels (TRPV5 and TRPV6) requires association of the S100A10annexin 2 complex. EMBO J 22:1478-1487

160. Borthwick LA, Neal A, Hobson L, Gerke V, Robson L, Muimo $\mathrm{R}$ (2008) The annexin 2-S100A10 complex and its association with TRPV6 is regulated by cAMP/PKA/CnA in airway and gut epithelia. Cell Calcium 44:147-157

161. Borthwick LA, McGaw J, Conner G, Taylor CJ, Gerke V, Mehta A, Robson L, Muimo R (2007) The formation of the cAMP/ protein kinase A-dependent annexin 2-S100A10 complex with cystic fibrosis conductance regulator protein (CFTR) regulates CFTR channel function. Mol Biol Cell 18:3388-3397

162. Borthwick LA, Riemen C, Goddard C, Colledge WH, Mehta A, Gerke V, Muimo R (2008) Defective formation of PKA/CnAdependent annexin 2-S100A10/CFTR complex in DeltaF508 cystic fibrosis cells. Cell Signal 20:1073-1083

163. Girard C, Tinel N, Terrenoire C, Romey G, Lazdunski M, Borsotto M (2002) p11, an annexin II subunit, an auxiliary protein associated with the background $\mathrm{K}^{+}$channel, TASK-1. EMBO J 21:4439-4448

164. Okuse K, Malik-Hall M, Baker MD, Poon WY, Kong H, Chao MV, Wood JN (2002) Annexin II light chain regulates sensory neuron-specific sodium channel expression. Nature 417:653-656

165. Foulkes T, Nassar MA, Lane T, Matthews EA, Baker MD, Gerke V, Okuse K, Dickenson AH, Wood JN (2006) Deletion of annexin 2 light chain p11 in nociceptors causes deficits in somatosensory coding and pain behavior. J Neurosci 26:10499-10507

166. Donier E, Rugiero F, Okuse K, Wood JN (2005) Annexin II light chain p11 promotes functional expression of acid-sensing ion channel ASIC1a. J Biol Chem 280:38666-38672

167. Reither G, Schaefer M, Lipp P (2006) PKCalpha: a versatile key for decoding the cellular calcium toolkit. J Cell Biol 174:521-533

168. Marin-Vicente C, Gomez-Fernandez JC, Corbalan-Garcia S (2005) The ATP-dependent membrane localization of protein kinase Calpha is regulated by $\mathrm{Ca}^{2+}$ influx and phosphatidylinositol 4,5-bisphosphate in differentiated PC12 cells. Mol Biol Cell 16:2848-2861

169. Schmitz-Peiffer C, Browne CL, Walker JH, Biden TJ (1998) Activated protein kinase $\mathrm{C}$ a associates with annexin VI from skeletal muscle. Biochem J 330:675-681

170. Monastyrskaya K, Hostettler A, Buergi S, Draeger A (2005) The NK1 receptor localizes to the plasma membrane microdomains, and its activation is dependent on lipid raft integrity. J Biol Chem 280:7135-7146

171. Weerth SH, Holtzclaw LA, Russell JT (2007) Signaling proteins in raft-like microdomains are essential for $\mathrm{Ca}^{2+}$ wave propagation in glial cells. Cell Calcium 41:155-167

172. Orito A, Kumanogoh H, Yasaka K, Sokawa J, Hidaka H, Sokawa Y, Maekawa S (2001) Calcium-dependent association of annexin VI, protein kinase $\mathrm{C}$ alpha, and neurocalcin alpha on the raft fraction derived from the synaptic plasma membrane of rat brain. J Neurosci Res 64:235-241

173. Dubois T, Mira JP, Feliers D, Solito E, Russo-Marie F, Oudinet JP (1998) Annexin V inhibits protein kinase C activity via a mechanism of phospholipid sequestration. Biochem J 330:12771282

174. Rothhut B, Dubois T, Feliers D, Russo-Marie F, Oudinet JP (1995) Inhibitory effect of annexin $\mathrm{V}$ on protein kinase C activity in mesangial cell lysates. Eur J Biochem 232:865-872

175. Raynal P, Hullin F, Ragab-Thomas JM, Fauvel J, Chap H (1993) Annexin 5 as a potential regulator of annexin 1 phosphorylation by protein kinase $\mathrm{C}$. In vitro inhibition compared with quantitative data on annexin distribution in human endothelial cells. Biochem J 292:759-765

176. Sato H, Ogata H, De Luca LM (2000) Annexin V inhibits the 12-O-tetradecanoylphorbol-13-acetate-induced activation of Ras/extracellular signal-regulated kinase (ERK) signaling pathway upstream of Shc in MCF-7 cells. Oncogene 19:2904-2912

177. Marin-Vicente C, Nicolas FE, Gomez-Fernandez JC, CorbalanGarcia S (2008) The PtdIns(4,5)P2 ligand itself influences the localization of PKCalpha in the plasma membrane of intact living cells. J Mol Biol 377:1038-1052

178. Guerrero-Valero M, Marin-Vicente C, Gomez-Fernandez JC, Corbalan-Garcia S (2007) The C2 domains of classical PKCs are specific PtdIns(4,5)P2-sensing domains with different affinities for membrane binding. J Mol Biol 371:608-621

179. Hancock JF, Parton RG (2005) Ras plasma membrane signalling platforms. Biochem J 389:1-11

180. Quilliam LA, Rebhun JF, Castro AF (2002) A growing family of guanine nucleotide exchange factors is responsible for activation of Ras-family GTPases. Prog Nucleic Acid Res Mol Biol 71:391-444

181. Donovan S, Shannon KM, Bollag G (2002) GTPase activating proteins: critical regulators of intracellular signaling. Biochim Biophys Acta 1602:23-45

182. Chow A, Gawler D (1999) Mapping the site of interaction between annexin VI and the p120(GAP) C2 domain. FEBS Lett 460:166-172

183. Chow A, Davis AJ, Gawler DJ (1999) Investigating the role played by protein-lipid and protein-protein interactions in the membrane association of the p120GAP CaLB domain. Cell Signal 11:443-451

184. Grewal T, Evans R, Rentero C, Tebar F, Cubells L, de Diego I, Kirchhoff MF, Hughes WE, Heeren J, Rye KA, Rinninger F, Daly RJ, Pol A, Enrich C (2005) Annexin A6 stimulates the membrane recruitment of p120GAP to modulate Ras and Raf-1 activity. Oncogene 24:5809-5820

185. Rentero C, Evans R, Wood P, Tebar F, Vila de Muga, Cubells L, de Diego I, Hayes TE, Hughes WE, Pol A, Rye KA, Enrich C, Grewal T (2006) Inhibition of H-Ras and MAPK is compensated by PKC-dependent pathways in annexin A6 expressing cells. Cell Signal 18:1006-1016

186. de Muga SV, Timpson P, Cubells L, Evans R, Hayes TE, Rentero C, Hegemann A, Reverter M, Leschner J, Pol A, Tebar F, Daly RJ, Enrich C, Grewal T (2008) Annexin A6 inhibits Ras signalling in breast cancer cells. Oncogene 22:363-377. doi: 10.1038/onc. 2008.386

187. Mussunoor S, Murray GI (2008) The role of annexins in tumour development and progression. J Pathol 216:131-140

188. Rytomaa M, Mustonen P, Kinnunen PK (1992) Reversible, nonionic, and $\mathrm{pH}$-dependent association of cytochrome $\mathrm{c}$ with cardiolipin-phosphatidylcholine liposomes. J Biol Chem 267:22243-22248

189. Thuduppathy GR, Terrones O, Craig JW, Basanez G, Hill RB (2006) The N-terminal domain of Bcl-xL reversibly binds 
membranes in a pH-dependent manner. Biochemistry 45:14533-14542

190. Yoo SH (1995) Purification and pH-dependent secretory vesicle membrane binding of chromogranin B. Biochemistry 34:8680-8686

191. Gu F, Gruenberg J (2000) ARF1 regulates pH-dependent COP functions in the early endocytic pathway. J Biol Chem 275:8154-8160

192. Sheldon C, Church J (2002) Intracellular pH response to anoxia in acutely dissociated adult rat hippocampal CA1 neurons. J Neurophysiol 87:2209-2224

193. Chesler M (2005) Failure and function of intracellular pH regulation in acute hypoxic-ischemic injury of astrocytes. Glia 50:398-406

194. Fitts RH (1994) Cellular mechanisms of muscle fatigue. Physiol Rev 74:49-94

195. Lipton P (1999) Ischemic cell death in brain neurons. Physiol Rev 79:1431-1568

196. Cannizzaro C, Monastero R, Vacca M, Martire M (2003) [3H]-DA release evoked by low $\mathrm{pH}$ medium and internal $\mathrm{H}^{+}$ accumulation in rat hypothalamic synaptosomes: involvement of calcium ions. Neurochem Int 43:9-17

197. Yagi J, Wenk HN, Naves LA, McCleskey EW (2006) Sustained currents through ASIC3 ion channels at the modest $\mathrm{pH}$ changes that occur during myocardial ischemia. Circ Res 99:501-509

198. Hu R, Jin H, Zhou S, Yang P, Li X (2007) Proteomic analysis of hypoxia-induced responses in the syncytialization of human placental cell line BeWo. Placenta 28:399-407

199. Denko N, Schindler C, Koong A, Laderoute K, Green C, Giaccia A (2000) Epigenetic regulation of gene expression in cervical cancer cells by the tumor microenvironment. Clin Cancer Res 6:480-487

200. Sullivan DM, Wehr NB, Fergusson MM, Levine RL, Finkel T (2000) Identification of oxidant-sensitive proteins: TNF-alpha induces protein glutathiolation. Biochemistry 39:11121-11128

201. Caplan JF, Filipenko NR, Fitzpatrick SL, Waisman DM (2004) Regulation of annexin A2 by reversible glutathionylation. J Biol Chem 279:7740-7750

202. Kubista H, Hawkins TE, Patel DR, Haigler HT, Moss SE (1999) Annexin 5 mediates a peroxide-induced $\mathrm{Ca}^{2+}$ influx in B cells. Curr Biol 9:1403-1406
203. Sacre SM, Moss SE (2002) Intracellular localization of endothelial cell annexins is differentially regulated by oxidative stress. Exp Cell Res 274:254-263

204. Patchell BJ, Wojcik KR, Yang TL, White SR, Dorscheid DR (2007) Glycosylation and annexin II cell surface translocation mediate airway epithelial wound repair. Am J Physiol Lung Cell Mol Physiol 293:L354-L363

205. Babbin BA, Parkos CA, Mandell KJ, Winfree LM, Laur O, Ivanov AI, Nusrat A (2007) Annexin 2 regulates intestinal epithelial cell spreading and wound closure through Rho-related signaling. Am J Pathol 170:951-966

206. Babbin BA, Laukoetter MG, Nava P, Koch S, Lee WY, Capaldo CT, Peatman E, Severson EA, Flower RJ, Perretti M, Parkos CA, Nusrat A (2008) Annexin A1 regulates intestinal mucosal injury, inflammation, and repair. J Immunol 181:5035-5044

207. Lennon NJ, Kho A, Bacskai BJ, Perlmutter SL, Hyman BT, Brown RH Jr (2003) Dysferlin interacts with annexins A1 and A2 and mediates sarcolemmal wound-healing. J Biol Chem 278:50466-50473

208. McNeil AK, Rescher U, Gerke V, McNeil PL (2006) Requirement for annexin A1 in plasma membrane repair. J Biol Chem 281:35202-35207

209. Hayes MJ, Longbottom RE, Evans MA, Moss SE (2007) Annexinopathies. Subcell Biochem 45:1-28

210. Tanaka K, Einaga K, Tsuchiyama H, Tait JF, Fujikawa K (1996) Preparation and characterization of a disulfide-linked bioconjugate of annexin $\mathrm{V}$ with the B-chain of urokinase: an improved fibrinolytic agent targeted to phospholipid-containing thrombi. Biochemistry 35(3):922-929

211. Kenis H, Hofstra L, Reutelingsperger CP (2007) Annexin A5: shifting from a diagnostic towards a therapeutic realm. Cell Mol Life Sci 64:2859-2862

212. Tait JF (2008) Imaging of apoptosis. J Nucl Med 49:1573-1576

213. Gastardelo TS, Damazo AS, Dalli J, Flower RJ, Perretti M, Oliani SM (2009) Functional and ultrastructural analysis of annexin $\mathrm{A} 1$ and its receptor in extravasating neutrophils during acute inflammation. Am J Pathol 174:177-183

214. Perretti M, D'Acquisto F (2009) Annexin A1 and glucocorticoids as effectors of the resolution of inflammation. Nat Rev Immunol 9:62-70 